\title{
Señoríos Nobiliarios bajomedievales
}

\author{
Paulina lópez Pita *
}

I. INTRODUCCIÓN

II. EL SEÑORIOO. Concepto. Tipos y clases

III. EVOLUCIÓN EN LA FORMACIÓN DEL RÉGIMEN SEÑORIAL

IV. POLITICA DE LA MONARQUIÁA EN LOS SIGLOS BAJOMEDIEVALES

- La Casa de Trastámara

- El reinado de los Reyes Católicos

V. ESTUDIO METODOLÓGICO DEL RÉGIMEN SEÑORIAL

- Problemas planteados

- Estudios recientes

VI. CONCLUSIÓN

* UNED. 


\section{INTRODUCCIÓN}

Nos corresponde hoy ocuparnos de la formación y expansión de los Señoríos Nobiliarios bajomedievales. Tema de indudable interés por la importancia que alcanzaron en Castilla en los siglos XIV y XV, tanto desde el punto de vista socioeconómico como respecto al poder político que detentaron frente a la Monarquía, y por su trascendencia y proyección en la Edad Moderna.

Sin duda alguna como afirma Guilarte ${ }^{1}$ el alcance y significado del poder señorial deben ser valorados en contraste con la extensión de los poderes del Rey, recordemos que ya durante el gobierno de Alfonso $X$ se había producido una cierta tensión entre el poder real y la nobleza, la cual va a levantarse ante el incremento de los poderes regios ${ }^{2}$, y por otra parte, la monarquía sabía que no podía prescindir de la ayuda y del apoyo de la nobleza, de ahí la concesión de mercedes otorgadas por los monarcas, especialmente desde la entronización de la casa de Trastámara ${ }^{3}$. Esta tensión entre nobleza y monarquía será una constante en la Baja Edad Media.

El poder que alcanzó la nobleza fue tal, como podremos ir viendo a lo largo de esta exposición, que no sería posible tener una visión comple-

1 GuILARTE, A. M., en su importante obra El régimen señorial en el silgo xvi estudia y profundiza en la relación entre estas dos potestades: Corona y Nobleza.

${ }^{2}$ Vid. Quintanilla Raso, C., "Nobleza y Señoríos en Castilla en la Baja Edad Media. Aportaciones a la Historiografía reciente", en Anuario de Estudios Medievales, n. ${ }^{\circ} 14$. Barcelona 1984, pág. 623. La autora señala como desde la plena Edad Media las relaciones nobleza-monarquía se fundamentaban sobre la combinación de dos concepciones básicas y contrapuestas en torno al poder monárquico: la teocrática, según la cual la voluntad regia creaba la ley sin limitaciones, y la feudal que proclamaba el ejecicio del poder de forma pactada con la nobleza, cuyo consentimiento era necesario para el desarrollo de la voluntad monárquica.

${ }^{3}$ Véase en este aspecto la clásica obra de SuÁrez Fernandez, L., Nobleza y Monarquía. Puntos de vista sobre la historia política castellana del siglo XV. Valladolid 1975 (2. ${ }^{\text {a }}$ ed.). LaDero Quesada, M. A., "La Couronne et la noblesse au temps des Rois Catholiques (1465-1515)". Ponencia presentada al Coloquio sobre Pouvoir et institutions dans Europe au XVf-siècle. Tours, julio, 1984. Mitre FeRnández, E., Evolución de la nobleza en Castilla bajo Enrique III (1369-1406). Valladolid 1968. VALDEON BURUQUe, J., Enrique III de Castilla. La guerra civil y la consolidación del régimen 1366-1371. Valladolid 1966. 
ta de estos siglos bajomedievales si dejásemos de lado el estudio del Régimen Señorial en esta época, momento en el cual se produce el auge del mismo con el crecimiento de los señoríos nobiliarios.

Fue durante los siglos XIV y XV cuando se produce la señorialización del territorio de una manera efectiva, pues aunque este proceso se había iniciado con anterioridad, será durante el gobierno de la dinastía Trastamarista cuando se acreciente la señorialización de sus reinos. Como manifestaba el profesor Salvador de Moxó, los Trastámaras fueron mediante sus donaciones «la más caudalosa fuente de señoríos de Castilla» ${ }^{4}$.

$Y$ lo que revistió aún mayor importancia, y esto hay que tenerlo presente, es que algunos nobles llegaron a acumular tanto poder jurisdiccional que sus señorios van a constituir verdaderos estados dentro del Estado ${ }^{5}$. Esta señorialización trae consigo el aumento y el refuerzo de las soberanías señoriales, que se constituyen en verdaderos aparatos de Estado descentralizados, combinados como apunta J. M. Monsalvo, con una centralización monárquica muy acusada, da precisamente la medida de la organización política bajomedieval. Además, la concesión de algunos monopolios regios durante el gobierno de los últimos Trastámaras contribuyó a que los estados señoriales aumentasen su poder autónomo, por lo que Isabel Beceiro los denomina «principados en su funcionamiento práctico aunque mantenían ciertas limitaciones teóricas» ${ }^{6}$.

Fn suma, podemos afirmar que la nobleza castellana, ya poderosa desde los siglos XIII y XIV, va a mantener, debido al poder que alcanzó, una tensión con la realeza con la que va a mantener una peligrosa rivalidad política hasta el fin de la Edad Media.

${ }^{4}$ MoxO, S. DE,: «Los señoríos. En torno a una problemática para el estudio del régimen señorial», en Hispania, 1964, págs. 23 y sigs.

${ }^{5}$ PASTOR, R., «Reflexiones sobre los comienzos de la formación política feudovasallática en Castilla y León", en Realidad e imágenes del poder en España a fines de la Edad Media. Valladolid 1988. (Coord. Rucquoi). y Monsalvo, J. M., El sistema político concejil. El ejemplo del Señorio Medieval de Alba de Tormes y su concejo de Villa y Tierra. Salamanca 1988, pág. 30.

${ }^{6}$ Beceiro Pita, l., "Los estados señoriales como estructura de poder en la Castilla del siglo XV", en Realidad e imágen..., op. cit., pág. 297. En este trabajo la autora analiza los factores que van a proporcionar al noble una fuerza capaz de oponerse abiertamente al monarca: la función militar, el ejercicio de la justicia, la intervención sobre la moneda, la facultad de crear y controlar legislativamente las ferias y mercados y la apropiación de la fiscalidad regalina. 


\section{EL SEÑORIOO. CONCEPTO. TIPOS Y CLASES}

Antes de adentrarnos en el estudio de la formación y desarrollo de los señoríos y para proceder con un rigor metodológico en orden al conocimiento del Régimen Señorial es necesario que nos ocupemos, aunque sea brevemente, en clarificar el término de «Señorío» ?.

El señorío es algo más que una institución, afirmaba Moxó, ya que representa un complejo sistema de gobierno de los hombres, administración tributaria y explotación de la tierra.

Desde el siglo $\times$ la pequeña propiedad rústica fue dejando paso a la formación del gran dominio o "Señorío» al concentrarse la propiedad de la tierra en pocas manos, esos dominios territoriales estaban sujetos a la autoridad directa de sus dueños o señores, lo que va a traer consigo la creación de unos lazos de dependencia entre los habitantes de ese dominio y el señor del mismo, el cual había reunido bajo su autoridad, tierras, villas, aldeas, no siempre bajo el mismo grado, con sus moradores.

De acuerdo con las circunstancias del momento, el titular del señorío va a ir recibiendo del monarca un buen número de donaciones, tanto territoriales como de índole jurisdiccional, mediante las cuales irá incrementando su dominio solariego y su poder jurisdiccional, de tal forma que, como apuntábamos anteriormente, el Señorío llega a constituirse dentro del territorio del Estado como un distrito o "circunscripción» sometido directamente a la autoridad del «señor».

Con ello se fue generalizando lo que desde un punto de vista institucional denominamos "Régimen Señorial» que engloba la organización económica, social y jurídica derivada de las relaciones de dependencia señorial.

Así pues, en síntesis, encontramos que el señorío aparece originariamente como una ordenación humana y un sistema de explotación agraria de carácter rural derivado del gran dominio de la temprana Edad Media.

Moxó hablaba de la misión repobladora de la institución señorial y destacaba como una de las notas más positivas en la génesis y desarrollo del régimen señorial la función repobladora que lleva a cabo desde la

MOXÓ, S. DE, “El señorío legado medieval», en Cuadernos de Historia, 1, Madrid 1967, págs. $105-118$. 
plena Edad Media, y que con el paso del tiempo dejó de ser un factor importante de repoblación para constituirse en una fórmula autónoma de la administración local ${ }^{8}$.

Una vez expuesto esto, veamos que tipos de señoríos se forman en la época medieval. Voy a ceñirme a exponerlos brevemente, remitiendo a la lectura de los trabajos de Salvador de Moxó ${ }^{9}$.

Los señoríos nobiliarios desde su origen presentan dos modalidades: una es el llamado "señorío territorial», en el cual la potestad del señor sobre los habitantes de su tierra solamente se fundamentaba en el ejercicio por parte de aquél de algunos derechos sobre las gentes del «señorío" vinculados al "señor» por relación de dependencia económica y jurídico privada ${ }^{10} ; \mathrm{y}$, otra, sería el llamado «señorí jurisdiccional», en el que el señor estaba investido en su señorío de jurisdicción ordinaria y de parte de las facultades de la potestad real.

A lo largo de la Baja Edad Media el señorio jurisdiccional fue incrementándose, y lo más frecuente en los siglos bajomedievales era que el señor uniese a su condición de dueño de la tierra el ejercicio de la jurisdicción y algunas facultades del poder regio.

Por último, para encuadrar y poner de relieve la importancia de los señoríos nobiliarios, recordaré que, con independencia de su condición de territoriales o jurisdiccionales, se distinguen varias clases de señoríos, atendiendo a la institución que lo detentaba. Así encontramos la existencia de "señoríos de realengo", sometidos directamente al poder del rey, los cuales eran administrados por oficiales y agentes del monarca. Con los Trastámaras muchos de estos señoríos, van a ser cedidos a los nobles, provocando el consiguiente malestar de sus súbditos.

"Señoríos de abadengo", en los cuales era el abad el titular de la potestad señorial. Junto a estos estaban los «Maestrazgos», «Infantazgos», en manos de un maestre 0 de un infante, respectivamente. $Y$ otras clases de señoríos de carácter especial como fueron los «Señoríos de

${ }^{8}$ Moxo, S. DE, «Los señoríos. En torno a...,", op. cit., pág. 53.

"MoxÓ, S. DE, «Los señoríos. Estudio metodológico", Actas de las / Jornadas de metodologia aplicada de las ciencias históricas. Santiago 1975, págs. 163-173. Y «El señorío legado medieval...", op. cit., y "Los señoríos. En torno a...", op. cit.

${ }_{10}$ Conviene recordar que cuando se constituyen los señoríos medievales, con anterioridad a la Baja Edad Media, algunos de ellos se formaron sobre antiguos dominios patrimoniales del señor o de su linaje, y otros sobre territorios de nueva población colonizado por el propio rico-hombre que lo constituye. Moxó, S. DE, "Los señoríos. Estudio metodológico...", op. cit., pág. 166. 
behetrias», lugares donde sus habitantes podían elegir libremente a su señor; "Encomiendas", cesión temporal de un dominio hecha por el rey a un noble para que asumiese el amparo, protección y defensa de las tierras o castillos cedidos. Al mismo tiempo se constituyeron los "Señoríos nobiliarios", y es en ellos en los que vamos a fijar nuestra atención ya que fueron los predominantes en los siglos bajomedievales que ahora estudiamos.

\section{EVOLUCIÓN EN LA FORMACIÓN DEL RÉGIMEN SEÑORIAL}

La evolución del régimen señorial estuvo íntimamente ligada a la formación de la nobleza, y a la política llevada a cabo por los monarcas en relación con las necesidades de repoblación y con el apoyo que les prestó la nobleza en sus tareas políticas.

La nobleza se constituyó dentro de la sociedad medieval en el grupo predominante y rector, que contó con una serie de privilegios en el orden jurídico y con una fortuna patrimonial, más o menos variable, que la elevaron sobre el resto de la población, y que le van a permitir entrar a formar parte de la vida política. De su importancia dan buena muestra los estudios de eminentes historiadores ${ }^{11}$.

Dejando aparte a la «primitiva aristocracia», ligada al proceso de repoblación que contribuyó a consolidar y a aumentar el trabajo agrícola al recibir en premio a sus servicios militares núcleos solariegos, vamos a centrar nuestra atención en la «nobleza vieja» y especialmente en la llamada «nueva nobleza» ${ }^{12}$.

11 Barthelemy, D., L'Ordre seigneurial XI-X\| siècles. París. Seuil, 1990. Genicot, L., L'Economie rurales Namuroise au bas Moyen Age. Vol. II Les Hommes, la noblesse. Louvain 1960 y «La noblesse au Moyen Age dans l'ancienne France», en Annales, Economie, Societé, Civilisations, 1962. Contamine, P., La noblesse au Moyen Age. Essais à la memoire de Robert Boutruche. (Coord.) París 1976. DU PuY DE Clinchamps, P., La noblesse. París 1962. Duby, G., Hombres y estructuras de la Edad Media. Madrid 1977. Gerbet, M. C. «Les guerres et l'accès à la noblesse en Espagne de 1465 a 1592", Mélanges de la Casa de Velázquez, n. ${ }^{\circ}$ 8, 1972, págs. 295-326; y "Essai sur l'aparition d'une moyenne noblesse dans l'Estremadure de la fin du Moyen Age", A.E.M., 16. Barcelona 1986, págs. 557-571.

${ }^{12}$ Moxo, S. DE, "La nobleza castellano-leonesa en la Edad Media. Problemática que suscita su estudio en el marco de una historia social», en Hispania, 1970, págs. 7-27. 
Para Reyna Pastor ${ }^{13}$ la "vieja nobleza» no se gestó como mantenía Moxó ${ }^{14}$, en el siglo $\mathrm{XII}$, sino mucho antes, durante los siglos $x$ y xI, momento en el que el comienzo de la expansión cristiana va a posibilitar la gestión, especialmente en el siglox, del poder de la nobleza. En esta misma línea Martínez Sopena habla de la existencia de una nobleza de linaje desde los primeros avances de la Reconquista ${ }^{15}$.

Así pues encontramos que poder real y poder nobiliario se fueron gestando a la par por mutua necesidad y apoyo, nacieron como complementarios, pero en ocasiones con intereses contrapuestos.

Durante esta etapa, que abarcaría desde la segunda mitad del siglo $x$ hasta finales del siglo XI, en la que Reyna Pastor fija la primera etapa de la señorialización, se produjo la desaparición progresiva del alodio; y la lenta, pero sostenida, desaparición del campesino libre y su entrada en la dependencia señorial con la consiguiente aparición de nuevas cargas e impuestos que los campesinos debían satisfacer a sus señores. De esta manera el campesino fue perdiendo su relación directa con la tierra; y se fue restructurando la renta feudal, base económica de la implantación del feudalismo ${ }^{16}$.

Posteriormente, en los siglos bajomedievales, y más concretamente en el siglo XIV, uno de los siglos más controvertidos por su propia complejidad, tuvo lugar la formación de una «nueva nobleza» como consecuencia de la instauración de nuevas dinastías en los reinos peninsulares ${ }^{17}$.

El núcleo de linajes nobles que aparece en la cúspide nobiliaria al final del período Trastámara constítuirá la base altonobiliar que dominará el reino durante la Edad Moderna, citemos, entre otros, a los Ayala, Álvarez de Toledo, Velasco, Medinaceli, etc... solo una minoría de la noble-

13 PASTOR, R., "Reflexiones sobre los comienzos...", op. cit., págs. 13-19.

${ }^{14}$ MoxO, S. DE, "La nobleza castellano-leonesa en la Edad Media», op. cit., págs. 2749.

15 Martinez Sopena, P., La Tierra de Campos Occidental. Poblamiento, poder y comunidad del siglo $x$ al XII. Valladolid 1985, págs. 327-328.

${ }^{16}$ Sánchez Albornoz afirmaba que al mantener los reyes buen número de reservas del poder real en sus manos, no hubo feudalisno ni relaciones feudo-vasalláticas desarrolladas plenamente, y que si lo hubo fue imperfecto al menos hasta el siglo xIV. PASTOR, R., op. cit., pág. 14.

17 El declive y extinción de la vieja nobleza y la formación de la nueva nobleza fue estudiado por Moxó en su trabajo «De la nobleza vieja a la nobleza nueva. Transformación nobiliaria castellana en la Baja Edad Media", Cuadernos de Historia de España, 3. Madrid 1969, págs. 1-209; y en "La nobleza castellana en el siglo XIV», Anuario de Estudios Medievales, VII, 1970, págs. 503-511. 
za vieja $(20,5 \%)$ se integrará en los cuadros de la nueva nobleza, los Guzmán, Ponce de León, Mendoza, Manrique, Osorio, Guevara, Rojas, etcétera. ${ }^{18}$.

La desaparición de los linajes nobles más antiguos, durante el $2 .^{\circ}$ tercio del siglo XIV, no debe conducirnos a pensar que la nobleza perdiese prestigio como cuerpo politico-social, sino antes bien, las nuevas circunstancias políticas van a ofrecer grandes oportunidades a estos linajes nuevos, y lo que se produjo fue una renovación del marco social a través de estas familias y encontramos que la alta consideración social y la peculiar caracterización jurídica nobiliaria se traspasan incólumes de la vieja a la nueva nobleza castellana.

Recordemos que las estructuras políticas de la época no podían prescindir de los cuadros nobiliarios, y esto lo sabía muy bien la nueva nobleza quien va a heredar las antiguas apetencias de las viejas familias, y a la cual vamos a encontrar ocupando puestos cortesanos y los de mayor importancia en la administración.

Del real patrimonio saldrán un buen número de donaciones perpetuas, por lo que apurado éste, se «inventó», según refiere Sempere... «el maldito arbitrio de crear y negociar oficios inútiles de justicia y, gobierno», acrecentándose las aicaldías, escribanias, notarías, receptorias, etc... y otros infinitos títulos lucrativos que, a pesar de la nota de vileza, manifiesta el autor citado, con que se miraba el ejercicio de muchos de ellos, no por eso dejarán de ser objeto de la ambición de los señores ${ }^{19}$.

La nueva nobleza manifiesta pronto sus codicias por ocupar los puestos cortesanos y los de mayor realce en la administración, como eran los de condestables, mariscales, contadores mayores, etc... cargos en los que nos encontramos a Juan Hurtado de Mendoza, a Álvaro de Luna o al Marqués de Villena entre otros.

\section{Origen de los nuevos linajes}

Desde el punto de vista «territorial» la mayor parte de los nuevos linajes tienen su origen y procedencia en la Castilla septentrional, aunque también encontramos linajes cuyo origen se situa en la Castilla meridio-

${ }^{18}$ Moxó, S. DE, «De la nobleza vieja a la nobleza nueva...», op. cit., pág. 197.

19 Sempere, J., $\mathrm{H}^{2}$ de los vínculos y mayorazgos. Madrid, 1947, pág. 76, y LaMB, U., «La nobleza de sangre y los oficios tenidos por viles», Hidalguia, 1955, págs. 295-298. 
nal, como es el caso de los Toledo, los Albornoz, etc... o en Andalucía, origen de los Córdoba, Portocarrero o Dávalos.

Entre ellos están como en épocas anteriores miembros de la casa Real, son hijos de Fernando III, Alfonso X y Enrique II, como el linaje de Cerda, o Enríquez. Junto a estos linajes naturales del reino, se formaron otros de procedencia extranjera. Fueron numerosos pero, entre ellos, cabe resaltar la formación de linajes portugueses que arraigaron en Castilla, como puso de relieve el Profesor Mitre ${ }^{20}$. Junto a éstos, surgen otros de origen ultrapirenaico, como el de Bernal de Bearne, cuya familia formaría la casa de Medinaceli ${ }^{21}$. Otros procedían de los caballeros franceses o navarros venidos en tiempos de Enrique II $^{22}$.

Atendiendo a su origen «social», podríamos decir en términos generales, que la procedencia de esta nueva nobleza no es uniforme. Salvador de Moxó ${ }^{23}$ señaló cuatro orígenes: los que procedían de la propia familia Real o de ramas colaterales, sirva como ejemplo el caso de Alfonso Enriquez, señor de Medina de Rioseco; los hidalgos o caballeros, miembros ya de la nobleza ${ }^{24}$, que se elevaron en la propia jerarquía social ${ }^{25}$; Favoritos y consejeros de los Monarcas, a menudo de condición más humilde en su origen pero que gracias al favor regio van a situarse en un rango superior; y por último, los guerreros de fortuna, no solo de origen extranjero, como algunos de los que vinieron a Castilla con las Compañias que apoyaban a Enrique II, sino también naturales del Reino, que se desenvolvieron con éxito fuera de sus fronteras, como fue el caso de Rodrigo de Villandrando, conde de Ribadeo ${ }^{26}$.

${ }^{20}$ Mitre, E., “La emigración de los nobles portugueses a Castilla a fines del siglo XIV" en Hispania 104, págs. 513-525.

${ }_{21}$ MOxO, S. DE, "La nobleza castellano-leonesa», op. cit., pág. 54.

22 BeCEIro PITA, I., "La conciencia de los antepasados y la gloria del linaje en la Castilla bajomedieval”, en Relaciones de poder..., op. cit., págs. 347.

${ }^{23}$ MoxO, S. DE, “La nobleza castellano-leonesa en la Edad Media", op. cit, pág. 54. Véase para el caso de Sevilla, SánChez SAUS, R., "Los orígenes sociales de la aristocracia sevillana del siglo XV», en La España Medieval, 1986, págs. 118-119.

${ }_{24}$ Tal fue el caso de Andrés de Cabrera. Véase el trabajo de Molina Gutierrez, P., "Formación del patrimonio de los primeros marqueses de Moya", en La España Medieval, núm. 12, 1989, págs. 285-304.

${ }_{25}$ MEYER, J., refiere que hacen falta tres generaciones para que una familia ennoblecida se destaque de su medio de origen adscribiéndose a su nueva situación. Vid., La noblesse bretonne. París 1966, págs. 364 y 423-30. Moxó puntualizaba que esta consideración podiamos aplicarla a los linajes que alcanzaron en Castilla la «rica-hombria", elevándose sobre los otros hidalgos. Y por otra parte, la Partida II, t. XXI, habla de cuatro generaciones dentro de la nobleza en orden a la selección de los caballeros.

${ }^{26}$ Sobre la ascensión de este personaje durante la primera mitad del siglo xv. Véase el artículo de CALDERON ORTEGa, J. M., "La formación del señorío castellano y el mayorazgo 
Llegados a este punto cabe preguntarse qué diferencias existían entre ambos grupos nobiliarios. Es evidente, según los estudios realizados por Moxó, que se aprecia, como fenomeno social, una discontinuidad biológica entre la vieja nobleza y la nueva nobleza. Discontinuidad que aparece también en el orden patrimonial, donde se encuentran ciertas transformaciones que reflejan una nueva mentalidad en este ámbito.

La nueva nobleza siente recelo al fraccionamiento de su señorío, cosa que era habitual a mediados del siglo XIV, y va a mostrar un gran interés en mantener la unidad señorial como fórmula expresiva de su poderio en el orden rural, deseo que se va a lograr mediante la institución de los mayorazgos, la introducción del sistema fue concebida en palabras de Marc Bloch, como un medio de reforzar la propiedad nobiliaria que va a evitar la dispersión al tiempo que la concentra ${ }^{27}$.

Paralelamente al auge de esta nueva nobleza se observa en el orden institucional, el triunfo del señorío jurisdiccional frente a otra importante institución secular como las behetrías, que va a sufrir un duro golpe con la transformación nobiliaria que se opera en Castilla ${ }^{28}$.

No obstante encontramos que esta nueva nobleza mantiene ciertos ideales de épocas pasadas, ya que va a recoger buena parte de la mentalidad y de la forma de vida de la vieja nobleza. Un claro ejemplo lo tenemos en la práctica de las actividades guerreras, que, como es bien sabido, era una de las expresiones más vivas de la mentalidad caballeresca que va a continuar presidiendo el ideal de vida noble a lo largo del siglo XIV ${ }^{29}$, pues aunque la llamada Reconquista se encontraba paraliza-

de Rodrigo de Villandrando, conde de Ribadeo (1439-1448), en Anuario de Estudios Medievales, 16. Barcelona 1986, págs. 421-447.

${ }^{27}$ Esta institución tuvo sus comienzos en época de Alfonso $X$, según consta en la Partida V. Ley 44, t. 5. Véase Sempere, J., op. cit., págs. 85-86. Gerbet, M. C., «Majorat, strategie familiale et pouvoir royal en Castille d'après quelques exemples pris en Extremadure a la fin du Moyen Age", en Les Espagnes medievales mélanges offerts a Jean $G$. Dalche. Nice 1983, págs. 257-276. Molenat, J. P., "La volonté de durer: Majorat el capellanies dans la pratique toledane des XIII-XV siècles", en La España Medieval, V. (Homenaje a Sánchez Albornoz), t. II. Madrid 1986, pág. 684.

${ }^{28}$ Ferrari, A., Castilla dividida en dominios según el libro de las behetrias. Madrid 1958, pág. 111. Algunos linajes nobiliarios del circulo de caballeros que ascendían a la alta nobleza habían sido titulares de behetrías, como los Velasco y Sandoval, Vid. Moxó, S. DE, "La nobleza castellana...", op. cit., pág. 59. El linaje de los Velasco es uno de los ejemplos más representativos de la nobleza nueva creada en tiempos de Enrique II. Vid. Gonzalez CRESPO, E., "El patrimonio de los Velasco a través del libro de las behetrías. Contribución al estudio de la fiscalidad señorial», en Anuario de Estudios Medievales, 16. Barcelona 1986, pág. 239.

${ }_{29}$ Estos ideales de la Caballería quedan reflejados en la celebración de fiestas. Véase, ANdRÉS Diaz, R. DE, "Las fiestas de caballeria en la Castilla de los Trastámaras", en La Edad Media. Estudios en memoria de Sánchez Albornoz. Madrid 1986, T. I. págs. 81-107. 
da, seguia existiendo un clima de tensión, tanto en el exterior como en el interior de la Península, que va a permitir la superviviencia del ideal guerrero-caballeresco. Recordemos la célebre frase de D. Juan Manuel, recogída en el Libro de los Estados: "Los grandes señores viven siempre en grandes guerras».

Esta actividad guerrera no es óbice para que se produzca entre miembros de la alta nobleza una sensibilidad hacia el mundo de las artes, que va a desarrollarse paralelamente y que quedará plasmada en su doble faceta de creadores y de mecenas ${ }^{30}$.

\section{POLITICA DE LOS MONARCAS EN LOS SIGLOS BAJOMEDIEVALES}

\section{La casa de los Trastámaras}

Desde el último tercio del siglo XIV, con la llegada al trono de la Casa de Trastámara se produjo en Castilla la transformación de numerosos pueblos de realengo en lugares de señorío nobiliario, al tiempo que muchos tributos y contribuciones destinadas a la Hacienda real pasaron a engrosar las arcas de personajes particulares, lo cual ocasionó un grave quebranto para la hacienda castellana. Recordemos que en esos momentos el objetivo primordial de las monarquías occidentales era la organización de sus finanzas ya que constituían éstas uno de los pilares del nuevo orden político.

El primer monarca de la Casa de Trastámara. Enrique II, al inicio de su reinado concedió a los nobles una serie de mercedes, entregándoles tierras, rentas, jurisdicciones, etc... para asegurar y consolidar el gobierno de la nueva dinastía, especialmente en aquellas regiones que revestían un mayor peligro para la estabilidad del régimen.

Política de concesión de mercedes que el rey llevó a cabo incluso antes de ocupar el trono de Castilla en 1369. Así lo narra Sempere: «...

30 Véase en este sentido el trabajo de STEFANO, Luciana DE, La sociedad estamental en la Baja Edad Media española a la luz de la literatura de la época. Caracas 1966. Maraval, J. A., "La sociedad estamental castellana y la obra de don Juan Manuel», en Cuadernos Hispanoamericanos, LXVII, 1966, págs. 751-768. 
Las grandes empresas exigen grandes estímulos y recompensas, y careciendo el conde de Trastámara de dinero, alhajas y tierras con que pagar y premiar dignamente a sus aliados y vasallos, procuró contentarlos con promesas y donaciones de bienes que aún no poseía cuando se declaró rey en Calahorra el año de $1366 \ldots{ }^{31}$.

No obstante hay que poner de manifiesto que no fue continua la concesión de mercedes a lo largo del reinado del primer Trastámara. El profesor Valdeón en su estudio sobre las mercedes enriqueñas ${ }^{32}$ ha señalado que desde 1371, cuando se celebran las Cortes de Toro, hasta 1379 se produjo un freno en la concesión de donaciones.

Será precisamente a partir de entonces cuando la institución del mayorazgo comienze a generalizarse ${ }^{33}$; su significado e importancia quedan reflejados en un privilegio real otorgado en 1377: «... Et otro si porque los maiorazgos son muy provechosos y cumplen mucho al nuestro servicio en los nuestros regnos por que aquellos que los an nos puedan mejor servir por ellos que en otra manera por que ellos sean mas ricos y mas honrados ...» ${ }^{34}$.

En estas primeras concesiones que el monarca hace permitiendo la fundación de los mayorazgos, aparecen ciertas restricciones a favor de la Corona, como era la orden dada por el monarca en su testamento a cerca de que los bienes del mayorazgo revertiesen para sí en el caso de que el titular del mayorazgo muriese sin dejar sucesión directa. Cláusula que suscitó la protesta de los nobles a Juan I, en las Cortes de Guadalajara de $1390^{35}$.

Enrique II, mediante el otorgamiento de tales mercedes, trataba de consolidar su poder y de afianzar y mantener la paz en sus reinos y éste fue el fin que le movió a desprenderse de sus atributos. Pero al mismo tiempo, mediante tales concesiones, el rey recompensaba a sus súbditos

${ }^{31}$ Sempere, J., Historia de los vínculos y mayorazgos, op. cit., pág. 68.

32 VALDEON, J., "Notas sobre las mercedes de Enrique II", en Hispania, 1968, pág. 42. Durante el período de 1371 a 1379 sólo cabe destacar la concesión del ducado de Benavente.

${ }^{33}$ VALDEON, J., «Notas sobre las mercedes...", op. cit., incluye una relación de los mayorazgos creados en tiempos de Enrique II. Vid., págs. 42-46.

${ }^{34}$ VALDEON, J., «Notas sobre las mercedes...», op. cit., pág. 43.

${ }_{35}$ El rey Juan I deroga la cláusula de reversión a la Corona dispuesta por su antecesor tocante al fallecimiento del titular del mayorazgo sin sucesión directa legítima. Vid. BECEIRO, l., "La conciencia de los antepasados y la gloria del linaje en la Castilla Bajomedieval», en Realidad e imágenes del poder..., op. cit., pág. 331. 
e indirectamente les comprometía y ligaba con su causa, tal fue el caso de Garcí Álvarez de Toledo ${ }^{36}$.

Pero me atrevería a afirmar que, paradójicamente, las mercedes otorgadas por Enrique II van a ser la causa y el inicio de un progresivo debilitamiento de la monarquía, ya que esta política de donaciones de territorios del patrimonio regio, con la consiguiente jurisdicción de los mismos, que se hizo a los nobles para atraerles a su causa, fue seguida por los demás miembros de la Casa de Trastámara: Juan I, Enrique III y de una manera especial por Juan II y su hijo Enrique IV, to que va a contribuir a que la Corona perdiese importantes posesiones de su patrimonio con la consiguiente disminución de sus rentas y una enorme repercusión en la Hacienda Regia ${ }^{37}$.

En el reinado de Enrique IV el real patrimonio había llegado a tal pobreza que no sólo estaban "enajenadas por juro de heredad las mejores villas y lugares sino incluso rentas fijas de la Corona. Esta cesión por parte de la monarquía se hizo por diversos procedimientos, según refiere Hernando del Pulgar, bien como recompensa, o bien por compra a bajo precio; e incluso llegaron a venderse alcabalas del rey en blanco a cualquiera que quisiese comprarlas por muy poco dinero ${ }^{38}$.

Los monarcas fueron conscientes del daño que todo ello les causaba pero no encontraron otra salida para afianzarse en el trono y alcanzar la paz en el reino. Mediante las donaciones trataban no sólo de contentar a quienes les habían apoyado en las luchas dinásticas; así lo manifestaba Enrique II en su testamento: "... les ovimos de facer algunas gracias e mercedes porque nos lo avian bien servido e merescido... ${ }^{39}$, (recordemos que la victoria de Enrique II había sido obra de la nobleza); sino que

${ }^{36}$ Garci Álvarez de Toledo, maestre de Santiago, en nombre de Pedro I, residía en Toledo, ciudad cuya conquista resultó difícil para Enrique II, por lo que el Monarca se le atrajo a su causa a través de una negociación. El maestre deseaba tener un señorío propio, y Enrique II le hizo donación de la villa de Oropesa, (9-5-1366), a la que siguieron Valdecorneja, Piedrahita, el Barco de Ávila, Jarandilla y Tornavacas; rico patrimonio al sur de la sierra de Gredos. Vid. Franco Silva, A., "Oropesa: el nacimiento de un señorío toledano a fines del siglo XIV", en Anuario de Estudios Medievales. Barcelona 1985, págs. 303. Moxó, S. DE, Los antiguos señoríos de Toledo. Toledo 1975, pág. 56. Santos Canalejo, E., “Piedrahita, su comunidad de Villa y Tierra y los Duques de Alba en el siglo XV", en La España Medieval, 1986, págs. 1141-1174.

${ }^{37}$ Uno de los más beneficiados será Juan Pacheco, Marqués de Villena. Véase Frías, I., «Juan Pacheco. El Marqués de Villena, 1419-1479». Tesis Doctoral inédita.

38 Véase, Crónica de los Reyes Católicos, don Fernando y doña Isabel. Cap. 95, part. 2.

${ }^{39}$ VALDEÓN, J., "Notas sobre las mercedes...», op. cit., pág. 42. 
también deseaban atraerse a su causa a aquellos grupos nobiliarios más remisos a acatar su poder.

La nobleza, por su parte, conociendo la debilidad de los monarcas va a presionarles para sacar el mayor provecho y beneficio de estas donaciones. Cuenta la Crónica que los que vinieron con Enrique $\|$ «... le demandaron muchas donaciones e mercedes en los regnos de Castilla e de León...» ${ }^{40}$. Y ello traería consigo el consiguiente aumento de poder por parte de la nobleza, en detrimento del poder real. Muchos nobles solicitaron de la Corona la concesión de regalías que hasta entonces guardaba ésta celosamente, e hicieron valer su apoyo a Enrique IV para obtener la confirmación legal de mercados y ferias ${ }^{41}$. Hasta el reinado de Enrique IV el rey hacía a los nobles, ahora es la nobleza la que hace a los reyes según sus intereses ${ }^{42}$.

Esta política de los Trastámaras va a provocar, como más adelante veremos, el descontento casi generalizado de unos súbditos que veían cómo la Monarquía perdía sus tierras y riquezas en beneficio de una nobleza que trataba de sacar el máximo provecho cometiendo innumerables abusos.

\section{Consecuencias}

Como consecuencia de la política de donaciones practicada por los monarcas de la Casa de Trastámara, encontramos que el régimen señorial va a alcanzar durante el gobierno de esta dinastía, su momento de mayor plenitud y expansión, tanto en el orden «cuantitativo» como en el cualitativo.

Respecto al primero, el crecimiento numérico que se opera es un hecho fácilmente constatable. Los monarcas, desde Enrique II a Enrique IV, como hemos aludido ya, incrementaron las donaciones de señoríos. Moxó señala 170 señoríos de origen medieval, de los cuales sólo los de Cardiel, Orgaz y los comprendidos en el estado de Valdepusa,

to Sempere, J., op. cit., pág. 68.

${ }^{41}$ Durante el gobierno de Enrique III se celebraron numerosas ferias, como las de Piedrahita, o el Barco de Ávila. Véase Ladero QuesadA, M. A., Economía y poder en la Castilla del siglo Xv, págs. 380-383.

${ }^{42}$ Martín, J. L., La Península en la Edad Media. Barcelona 1978, pág. 726. 
tienen un origen anterior a los Trastámara ${ }^{43}$. Algunos de ellos procedían del realengo, y otros habían estado en poder de las Órdenes Militares, cuyos miembros los hubieron vendido o permutado con otros.

$\mathrm{Si}$ bien el crecimiento cuantitativo del Régimen señorial es significativo, y ésto es importante para su evolución, mayor importancia cobra aún, por su repercusión frente al poder real, el crecimiento "cualitativo" del mismo, veamos por qué.

Hasta el siglo XIV había predominado la formación de los llamados "señoríos solariegos o territoriales", es decir de aquellos señoríos donde su titular poseía únicamente el dominio del suelo, y estaba investido de potestades que derivaban de su poder dominical sobre los habitantes del mismo.

En los siglos bajomedievales, una de las ambiciones de los «señores» será alzarse con la facultad de juzgar a aquellos que vivían en su tierra, y de una manera paulatina lograrán ir sacando de la Corona esta facultad. Recordemos que en Francia, durante el gobierno de los primeros Capeto, los señores territoriales habían ido apropiándose del poder jurisdiccional ${ }^{44}$; y que, en Castilla, ya desde el gobierno de Alfonso XI (1325-1350) y de Pedro I (1350-1369) la Corona había dejado escapar de su control la administración de la justicia a favor de los titulares de diversos señoríos, como consecuencia de un precepto del Ordenamiento de Alcalá de 1348 (t. XXVII, ley $3 .^{2}$ ) por el cual se dispuso que a los "Señores" de los "Señoríos territoriales" a los que no se hubiese concedido expresamente la jurisdicción, pero que de hecho la viniesen ejerciendo por un espacio de tiempo de 40 años, ganasen por prescripción la legítima potestad jurisdiccional sobre sus dominios.

Fue durante el gobierno de la dinastía Trastámara cuando podemos afirmar que la institución señorial alcanza su plenitud, ya que en casi todas las donaciones reales se otorga al señor, como un atributo muy cualificado, la jurisdicción sobre su dominio (Reyna Pastor opina que sería equiparable al señorío banal francés o catalán) y que se recoge en

${ }^{43}$ Moxo había tomado como referericia las Relaciones Topográficas mandadas hacer por Felipe II. Vid. "El señorío legado medieval», en Cuadernos de Historia, 1967, pág. 107; y «Los señoríos. En torno a...», op. cit., pág. 23.

${ }^{44}$ Hinojosa señala que la cjurisdicción no surgió como atributo inherente al dominio territorial, sino como concesión especial del Príncipe, a quien estaba reservado el conocimiento de ciertas causas. Vid. El régimen señorial y la cuestión agraria en Cataluña en la Edad Media". Madrid 1905, pág. 127. Asimismo BLoch, M., explica que el señorío no implica en su esencia el ejercicio de la justicia. Vid. Caracteres originaux de l'Histoire rurale française. París 1949, pág. 81. 
todos los documentos mediante la fórmula cancilleresca conocida «... con la jurisdicción civil y criminal, alta y baja, mero e mixto imperio...».

Esta locución indicadora del traspaso pleno del poder jurisdiccional fue usada especialmente durante la primera etapa de gobierno de Enrique II, etapa que Hilda Grassotti denomina "período clásico», que abarcaría la época comprendida entre el suceso de Montiel y las Cortes de Toro de 1371. La citada autora pone de relieve como muchas de tales mercedes se caracterizan por el otorgamiento de las «alzadas de los pleitos», última reserva que había guardado la Corona para sí en el ámbito jurisdiccional ${ }^{45}$.

Este doble derecho del señor sobre su dominio, donde se funden estos dos elementos a los que nos hemos referido: solariego y jurisdiccional, da lugar a la formación del señorío, que Salvador de Moxó, llamó, «jurisdiccional pleno», en el que se conjuga el dominio sobre el territorio y la facultad de juzgar, la potestad sobre los habitantes del mismo y el cobro de los correspondientes gravámenes tributarios. Moxó introdujo además otro elemento estrechamente ligado a los anteriores, el vasallático, mediante el cual el titular del señorío gozaba de una amplia capacidad de mando sobre el campesino ${ }^{46}$.

Un hecho que hay que tener presente es que buena parte de los nuevos señoríos, que se instituyen a fines del siglo XIV, se fundan sobre tierras ya pobladas y no yermas como había ocurrido en la plena Edad Media, y entre las obligaciones que tendrá el nuevo titular figura la obligación de acoger a todos los solariegos que habitasen con anterioridad en el recién creado señorío, no pudiendo desalojarlos del predio que cultivasen ${ }^{47}$, de ahí que en los documentos de creación de un señorío se pida a los vecinos que «... reconozcan y acojan a sus señor, a quien deben acudir con sus pechos y tributos...", pero hay que tener también presente que esos habitantes gozaban de un estatuto y que, por regla general, el nuevo señor no va a respetarlo, y el vasallo va a perder de hecho, sus fueros, usos y costumbres, por lo cual, en muchas ocasiones, se va a producir una resistencia ante el dominio señorial. Citemos por ejemplo a los vecinos de Medina de Rioseco quienes se quejaron de que su señor, el almirante Alfonso Enríquez, "les habia tomado mucho previ-

45 GrassotTI, H., «Novedad y tradición en las donaciones 'con mero y mixto imperio' en León y Castilla», en Homenaje al Prof. J. Torres Fontes. Murcia 1987, t. I, págs. 732733.

46 Vid. Quintanilla Raso, C., «Nobleza y señoríos en Castilla durante la Baja Edad Media. Aportaciones de la historiografía recientes», op. cit., pág. 626.

47 Así lo recoge el Ordenamiento de Alcalá. Ley XIII, título XXXII. Valladolid 1960. 
Hegios...” ${ }^{48}$. O la resistencia que mostraron los vecinos de Fuensalida y Layos frente a sus respectivos señores, Pedro López de Ayala y Juan Carrillo, siendo necesaria la intervención del rey para restituir a éstos en sus señoríos ${ }^{49}$.

Son muchos los casos que podríamos citar en torno a este asunto, pero voy a referirme a uno en concreto por ser muy significativo ${ }^{50}$. En 1499 el entonces príncipe don Enrique concede en señorío la villa de Medellín a Rodrigo Portocarrero, e insta a los vecinos a que reciban al mismo por su señor. Pero, ante el temor de que se produjese una desobediencia a lo ordenado, hay constancia de que Enrique escribió una carta a los vecinos amenazándoles con proceder contra sus personas, oficios y bienes, por no obedecer a Portocarrero. Parece ser que esta carta no estaba fechada y que se había escrito simplemente como medida de precaución, por si hubiera sido necesario su uso ${ }^{51}$.

Respuesta de los vasallos

Ya hemos apuntado anteriormente como los súbditos de la Corona de Castilla se mostraron contrariados con el proceder de los monarcas, muchos de ellos, habitantes de los señoríos de realengo, vieron como su "poder económico» quedó dañado cuando esas tierras en las que habitaban pasaron al «dominio señorial» ya que sus nuevos titulares les agobiaban con nuevas y más fuertes cargas fiscales.

Los señores, necesitados de dinero y tratando de incrementar sus menguadas rentas, van a buscar nuevas fuentes de ingresos a costa de sus vasallos, exigiéndoles el pago de nuevos e ilegales tributos ${ }^{52}$. La nobleza castellana, afirma Beceiro, al igual que la francesa intentará su-

48 Martinez Sopena, P., El estado señorial de Medina de Rioseco bajo el Almirante Alfonso Enriquez. Valladolid 1977, pág. 120.

49 LóPez PITA, P., Layos, origen y desarrollo de un señorio nobiliario, el de los Rojas, Condes de Mora. Toledo 1988, pág. 47.

${ }^{50}$ Remito al trabajo de VALDEÓN, J., «Los movimientos antiseñoriales en Castilla en el siglo XIV", C.H.E. núm. 6. Madrid 1975, págs. 357-390.

${ }^{51}$ Cabrera, E., "Beatriz Pacheco y los orígenes del condado de Medellín», en Anuario de Estudios Medievales, núm. 15. Barcelona 1985, pág. 519.

${ }_{52}$ Así sucedió en la villa de Caracena cuando los vasallos sometidos a A. Carrillo, no pudiendo soportar los agravios que sufrieron, expusieron sus quejas a los Monarcas. Véase Ffranco SILVA, A., "Señores y campesinos en tierras de Soria a fines del siglo XV", en Homenaje al Prof. J. Torres Fontes. Murcia 1987, t. I, págs. 526-7. 
perar la crisis del siglo XIV a través de la Hacienda regia ${ }^{53}$. Esta situación provocó el que surgiese un movimiento antiseñorial. Los vasallos van a aprovechar todos los medios que estuvieron a su alcance para mostrar y presentar sus quejas al poder regio, como sucedió en todas las celebraciones de Cortes que convocaron los Trastámaras.

Las reuniones de Cortes, convocadas con relativa frecuencia por Enrique II y Juan I, van a proporcionar a los procuradores de las ciudades el mejor medio para denunciar los males que les aquejaban. Por ello son de enorme interés los datos que nos ofrecen los Cuadernos de Cortes, ya que en ellos se recogen las denuncias del estamento popular y las respuestas dadas por los respectivos monarcas ${ }^{54}$.

Así por ejempio, en las Cortes de Toro de 1371, el pueblo de Castilla, claro defensor del señorío real, va a dejar sentir a través de sus procuradores su malestar ante la improcedente actitud de algunos señores. Enrique II reconoce, ante la $3 .^{a}$ petición formulada sobre la renovación de mercedes ya concedidas, que había hecho grandes mercedes ya que, según su parecer, correspondía a los monarcas «facer grandes mercedes a los que lealmente les sirven y que sean duraderas para siempre...» pero al mismo tiempo manifestaba que en adelante se guardaría, cuanto pudiese, de no dar más, aunque añade que «si algunas dieremos que las daremos en manera sea nuestro servicio, e pro de los nuestros regnos", con ello dejaba, no obstante, el camino libre para efectuar nuevas donaciones ${ }^{55}$.

Enrique II conocía los inconvenientes y daños que de las enajenaciones perpetuas de bienes de la Corona se producían, y así lo reconoció en Toro en 1371, pero temía que de revocar o restringir sus mercedes podrian renovarse los resentimientos y discordias de los nobles, y como consecuencia de ello se frustaría su proyecto político. Poco tiempo después, en las Cortes de Burgos de 1373, el estado llano mostró su malestar por los abusos que los nobles cometían en materia jurisdiccional. Denuncia que se repetiría en las Cortes celebradas en 1393. En Madrid, los procuradores piden al monarca que ponga freno a ios abusos en las

${ }^{53}$ BECEIRO, l. «Los estados señoriales como estructura de poder en la Castilla del siglo XV", en Realidad e imagen, op. cit., págs. 304-305.

54 Vid. VALDEÓN, J., "Las Cortes de Castilla y las luchas políticas en el siglo XV", en A.E.M. núm. 3. Barcelona 1966.

${ }^{55}$ Sempere, J., op. cit., págs. 68-69. 
concesiones de rentas y privilegios a los miembros de la nobleza ${ }^{56}$. En esta misma línea están las peticiones formuladas al rey Juan II en las Cortes de Valladolid de 1442, donde los representantes del reino piden que se revoquen los mercedes concedidas sobre enajenación del patrimonio real y que se abstuviese el monarca de conceder otras nuevas.

A pesar de las promesas hechas por el monarca, cuando vuelve a convocar cortes su hijo Enrique IV, en Salamanca en 1465, en Ocaña 1469, y en Santa María de Nieva 1473, encontramos que se repiten este mismo tipo de peticiones.

Enrique IV justifica su política y la de sus antecedosres por haberse visto obligado a ella por las necesidades en que se encontraba para consolidar el poder y la unidad del reino, y se limita a prometer que cuando las circunstancias del reino lo permitiesen, accedería a su's peticiones.

Estas respuestas no fueron del agrado de los procuradores, por lo que serán las propias villas y ciudades del reino las que se levanten contra el rey, para defender sus derechos, como así sucedió en la ciudad de Córdoba bajo los Sotomayor de Belalcázar ${ }^{57}$, o el movimiento que protagonizó la villa de Sepúlveda ${ }^{58}$. Isabel del Val-Valdivieso en su estudio sobre la resistencia al dominio señorial al final del reinado de Enrique IV, nos presenta algunos ejemplos concretos de la sublevación de las ciudades y villas del reino, como fue el caso de Trujillo, San Felices de los Gallegos, Ágreda, Aranda, Salamanca y Moya, negándose a abandonar su situación de realengo ${ }^{59}$.

Son muchos los casos que, gracias al avance en la investigación de los movimientos antiseñoriales, conocemos hoy día. Citemos, entre otros, la protesta de los vecinos de Peñaranda de Bracamonte contra su señor, Álvaro de Ávila; o las quejas de los vecinos de Lerma contra los Sando-

56 Mitre, E., "Los cuadernos de cortes castellano-leonesas (1390-1407). Perspectivas para su estudio en el ámbito de las relaciones sociales", en Actas de las 1. Jornadas de metodología aplicada de las Ciencias Históricas. Santiago 1975, pág. 289. Y Mitre, E. "Cortes y política económica bajo Enrique III», C.H.E., 6. Madrid 1975, pág. 404.

57 Cabrera, E., «La oposición de las ciudades al régimen señorial. El caso de Córdoba frente a los Sotomayor de Belazcázar". Hisioria, Instituciones y documentos, I. Sevilla 1974, págs. 13-39.

58 GonzÁlez Ruiz-ZorRilla, A., «La resistencia al dominio señorial: Sepúlveda bajo los Trastámaras", en Cuadernos de Historia, 3, 1969.

59 DEL VAL-VALdivieso, 1., «Resistencia al dominio señorial al final del reinado de Enrique IV", en Hispania, 1974, págs. 53-104, y "Reacción de la nobleza vizcaína ante la crisis bajomedieval", en La España medieval. Estudios en Memoria de S. de Moxó. T. II. Madrid 1982, págs. 695-70. 
val, sucesos que nos han dado a conocer los estudios de A. Franco Silva ${ }^{60}$; o la resistencia presentada por los vecinos de Oropesa para reconocer y acatar a Garci Álvarez de Toledo, que motivaron que la toma de posesión de la citada villa no se produjese hasta siete meses después de haberle sido concecida la villa por el rey Enrique $\mathrm{II}^{6 !}$.

\section{El reinado de los Reyes Católicos}

Cuando los Reyes Católicos se hacen con el poder, el régimen señorial se encuentra en plena pujanza, y como era su deseo controlar bajo su mandato, y por ellos mismos, los distintos reinos que habían reunido, van a tratar de frenar a toda costa el poder que habían alcanzado los nobles, y van a intentar debilitar, de modo especial, a ciertos linajes nobiliarios que se opusieron a Isabel en los comienzos de su reinado ${ }^{62}$.

El logro de conseguir que una Corona fuerte y que una nobleza estuviese sometida no fue una tarea fácil de realizar. Porque, no podemos olvidar que la nobleza había jugado un papel importante en la reciente guerra mantenida con Portugal, y también durante la conquista del reino de Granada, sucesos ambos cuyo resultado satisfactorio era de enorme trascendencia para los monarcas, por ello Isabel y Fernando no pudieron dejar de recompensar de alguna manera a los súbditos que les sirvieron en tales empresas; $y$ una forma de gratificarles y premiarles por su actuación fue mediante la firma de mercedes de villas y lugares, pues en aquel tiempo estaba muy arraigada y propagada la opinión de que las recompensas y propios más útiles y honoríficos consistían en tales mercedes; a pesar del desagrado que ésto les causaba, y de una manera especial a la reina Isabel quien, en 1475, había afirmado: «...que a los reyes convenia conservar las tierras, porque enagenandolas perdian las rentas, de que deben facer mercedes para ser amados e disminuían su poder para ser temídos...» ${ }^{63}$. No obstante, sabemos que los Reyes Ca-

${ }^{60}$ Franco SIllva, A., «El mariscal Álvaro de Ávila y los orígenes del Condado de Peñaranda de Bracamonte", en Estudios de Historia y Arqueología medievales, V. Cádiz; y "El linaje Sandoval y el señorío de Lerma en el siglo XV», en El pasado histórico de Castilla y León. Burgos 1983, Vol. I, págs. 133-149.

${ }^{61}$ Franco Silva, A., «Oropesa, el nacimiento...», op. cit., págs. 304-305. La concesión de la villa tuvo lugar el día 9 de mayor de 1366, y la toma de posesión de la misma se efectuaba el día 4 de diciembre de ese mismo año.

${ }^{62}$ Moxo, S. DE, «El señorío, legado medieval», op. cit., págs. 110-113.

${ }^{63}$ Crónica de los Reyes Católicos, op. cit., cap. 4. 
tólicos concedieron algunos señoríos en Almería en premio a la ayuda que los nobles les habían prestado en $1492{ }^{64}$.

Así pues encontramos que los Reyes Católicos van a conceder señoríos de similares características a los otorgados por sus antecesores los Trastámaras ${ }^{65}$. $Y$ aunque trataran de alejar a la nobleza de los cargos políticos y administrativos que habían venido ocupando, admitieron los privilegios económicos de que gozaban.

Hoy día la idea de que los Reyes Católicos llevaron a cabo una política antinobiliaria, como defendía la historiografía tradicional, es rechazada por la mayor parte de los autores que se han ocupado del tema, y buena prueba de ello fue el "sistema de pactos" que los monarcas aplicaron en la reconciliación con los nobles ${ }^{66}$; sirva como ejemplo de esta política pactista, la respuesta que la real Chancillería dio a los vecinos de Caracena (30-4-1499), después de que en 1498 acusasen a su señor Alonso Carrillo de haberles obligado a pagar nuevos e ilegales tributos sin tener título para ello. La Justicia real ante esta demanda resuelve la situación con un «moderado castigo» para el citado señor, pués únicamente le ruega que solicite la licencia adecuada para tal cobro ${ }^{67}$.

Esta política no fue un obstáculo para que los monarcas trataran de frenar de alguna manera el auge de la nobleza mediante una serie de disposiciones. En las Cortes de Toledo de 1480, se trató de remediar los abusos indicados, ya que cada vez hacían más pobre el erario. Los procuradores del reino, por su parte, pidieron que se anulasen todos los juros y enajenaciones hechas por Enrique IV, pero considerando que entre ellos podría haber algunos muy justos, se determinó hacer una rigurosa revisión de las causas y medios por los que se hubieran obtenido. Del resultado de aquella información, los Reyes Católicos dictaron una ordenanza por la cual algunos de áquellos se mantuvieron, otros se revocaron por completo, como fue el caso del Marqués de Villena, y otros se redujeron a la mitad, al tercio o al cuarto, según se estimaron los méritos para su otorgamiento, al considerar que su cuantía era desproporcionada con la causa o servicio que lo motivaron. La reducción de

${ }^{64}$ Segura, C. "Realengo y señorío en la tierra de Almeria", en La España Medieval. Estudios en memoria de S. de Moxó. T. II, Madrid 1982, págs. 595-613.

${ }^{65}$ Concediendo asimismo facultad para fundar mayorazgos, como el otorgado a Francisco de Rojas en 1501. López PitA, P., op. cit., pág. 91.

${ }_{66}$ Martínez Moro, J., Renta feudal en la Castilla del siglo xv: Los Stuñiga. Valladolid 1973, pág. 19.

67 Franco SILVA, A., "Señores y campesinos en tierras de Soria...", op. cit., págs. 526531. 
juros en 1480 afectó de una manera especial a la pequeña y media nobleza ${ }^{68}$.

En la Pragmática de Medina del Campo (28 de octubre de 1480) que los Reyes Católicos dirigieron a los señores cuya conducta no se aprobaba, dieron otras disposiciones tal como el reconocimiento de la libertad de movimientos de los vasallos del régimen señorial, a los que se les concedía libertad para pasar al realengo o a otro dominio con sus bienes muebles, anulando cualquier ordenanza señorial que fuese en contra. Sin embargo, a la hora de ponerlo en práctica, muchos vasallos no pudieron ejercer este derecho ya que van a encontrar la oposición del concejo, quien por inspiración del señor, les va a impedir cambiar de residencia, vender o arrendar sus bienes inmuebles, imponiéndoles, en suma, múltiples trabas para llevarlo a cabo ${ }^{69}$.

Asimismo se encuentran otras normativas: en las disposiciones testamentarias de la reina Isabel. En su testamento, otorgado en otoño de 1504 en Medina del Campo, la reina reconocía «el detrimento y deminución de la Corona... y del bien público..." ${ }^{70}$ y confesaba que se habian visto obligados a despachar mercedes de vasallos de la Corona por necesidades e importunidades, las cuales no habían sido otorgadas por su libre voluntad, y pide, incluso, a sus herederos que anulasen las mercedes nuevas.

Parece ser que la última voluntad de la reina no tuvo importantes consecuencias, pues no sólo no se hizo efectiva la anulación de la percepción de alcabalas, tercias y otras rentas de la Corona que estaban en manos de algunos linajes nobles, sino que incluso se otorgaron nuevas mercedes de tercias desde finales del siglo XV, como sucedió con los Stuñiga ${ }^{71}$.

No obstante, los Reyes Católicos tratando de mantener su autoridad y de enmendar los vicios de la jurisprudencia, existentes hasta entonces, llevaron a cabo una reforma legislativa con la promulgación de las Leyes de Toro, en las cuales se trataban muchas y variadas materias, y entre

\footnotetext{
${ }^{68}$ Matilla Tascón, A., Declaratorias de los Reyes Católicos sobre la reducción de juros y otras mercedes. Madrid 1966, pág. 66.

${ }^{69}$ GILlarte, A. M. El régimen señorial, op. cit., págs. 120-122. Y sobre lo sucedido en los sigios XII y XIII, MarTin, J. L., “¿Campesinos de remensa en Castilla y León? (siglos XIIXIII)", en La España Medieval. Homenaje a Salvador de Moxó, Madrid 1981, págs. 37-48.

70 García y Garcia de Castro, R., Virtudes de la reina Católica. Madrid 1956.

71 Los Stuñiga fueron una de las principales familias que se encumbran en el reino de Castilla después de la crisis del siglo xiv. Vid. Martinez Moro, J., La renta feudal en la Castilla..., op. cit.
} 
ellas, nos interesa destacar, la que trataba sobre la regulación en la fundación de los mayorazgos, uno de cuyos aspectos más sobresalientes fue la ampliación de la facultad a vincular bienes raíces (Ley XLVI) ${ }^{72}$.

Lo que es indudable es que Isabel y Fernando, agobiados por los problemas de la Hacienda regia, no encontraron más salida que la venta de alcabalas, medida que tomarán también otros monarcas posteriormente, Carlos I y Felipe $1{ }^{73}$.

\section{ESTUDIO METODOLÓGICO DEL RÉGIMEN SEÑORIAL}

Es conveniente ahora que dediquemos unas palabras al estudio del régimen señorial. ¿Cuál es la metodologia que debemos seguir a la hora de abordar cualquier trabajo sobre esta institución, en cierta medida, tan compleja?

El régimen señorial como hemos podido ir viendo a lo largo de esta exposición, está constituido por un conjunto de instituciones muy diversas, y al mismo tiempo cambiantes. Ciertos caracteres se nos presentan comunes para el régimen señorial en su conjunto, pero cada señorío, en particular, vendrá caracterizado por una serie de condicionamientos sociales, económicos, políticos existentes desde el momento de su fundación.

Por lo cual el estudio de un señorío, si queremos hacerlo con rigor metodológico, debe fundamentarse en el análisis y conocimiento de los distintos elementos que lo integran y que caracterizan y particularizan al propio señorío; en síntesis podríamos señalar los siguientes:

- Constitución del señorío:

- Fecha y circunstancias que motivaron su creación.

- Fundador: origen y genealogía.

- Tipo de señorío.

- Patrimonio señorial.

72 Nolasco de Llano, P., Compendio a los Comentarios extendidos por el maestro Antonio Gómez a las 83 Leyes de Toro. Madrid 1975. Ed. Fácsimil, 1981, pág. 109 (Ley $\mathrm{XL}$ ), y pág. 237 (Ley XLVI).

${ }_{73}$ Moxo, S. DE, "La venta de alcabalas en los reinados de Carlos I y de Felipe Il», Anuario de Historia del Derecho Español, t. XLI, 1971, págs. 487-554. 
- Régimen de gobierno del señorío:

- Relaciones entre el señor y el vasalio.

- Papel político y potestad jurisdiccional de los titulares del mismo.

- «Status» de los hombres del señorío.

- Actitud de los vasallos (¿Hubo resistencia antiseñorial?)

- Fuentes de ingresos:

- Rentas de carácter territorial (se abonan por el disfrute y explotación de una heredad).

- Fiscalidad jurisdiccional (derivadas de la autoridad del señor sobre el señorio).

- Fiscalidad regaliana (rentas pertenecientes a la Corona).

- Explotación de sus propiedades agrarias.

- Balance e importancia económica de las mismas.

- Costumbres y formas de vida. (Actitudes ante la vida y la muerte.)

- Inventario de sus bienes domésticos. Objetos de uso cotidiano. La vivienda.

[Ellos nos pueden proporcionar noticias valiosísimas para conocer muchos aspectos de un noble: riqueza, posición social, su cultura, etc...].

Lógicamente cuando se aborda el estudio de un señorío concreto, nos vamos a encontrar con dificultades para poder desarrollar en profundidad cada uno de los puntos señalados, ya que con frecuencia las fuentes documentales de que disponemos no son todo lo completas como cabría esperar sobre todo hasta el siglo XIV y de una manera especial en lo referente a las clases y niveles de rentas, campo de la fiscalidad bastante complejo.

Hay que tener presente que con el transcurso del tiempo y debido a causas climatológicas y bélicas, muchos legajos que se hallaban en archivos particulares, al igual que ocurrió, en ocasiones, con los que se podían encontrar en archivos del Estado, se han perdido. A veces por motivos jurídicos se sacaron de su lugar y no se volvieron a reemplazar en el mismo. 
¿Qué problemas presentan los estudios de los señoríos?

El estudio del régimen señorial tropieza con grandes dificultades, a veces casi insuperables. Las fuentes que debemos utilizar se encuentran, en su mayor parte, en los Archivos nobiliarios, de algunos de ellos conocemos su documentación por haberse dado a conocer a través de su catalogación, como ocurre con los archivos de la Casa de Alba, de Medinaceli o Frías, o bien porque, con el paso del tiempo, algunos fondos de los archivos nobiliarios pasaron a formar parte de los fondos documentales de los Archivos públicos por diversos motivos.

No obstante, existen otros muchos archivos particulares que guardan importantes colecciones documentales pero que, debido a su carácter privado no resulta fácil el acceso a la lectura de sus fondos. En este último caso, es necesario en primer lugar, localizar esa documentación, ya que a veces por herencia o por tener mayor interés en su conservación el archivo, ha pasado a manos de algún miembro de la familia que no ostenta el título nobiliario por el cual conocemos la existencia de un determinado señorío, e incluso puede haberse producido la venta de los mismos, lo cual complica aún más su localización.

Junto a estos archivos particulares, es obligada la consulta de la documentación que se guarda en el Archivo Histórico Nacional, en el Archivo General de Simancas, en la Biblioteca Nacional, en la Real Academia de la Historia, y en los respectivos Archivos Municipales y Provinciales del área geográfica donde estuviese ubicado el señorío.

\section{Estudios recientes}

A pesar de estas dificultades se ha producido un avance considerable en el estudio del régimen señorial. Desde el momento en que aparecieron los primeros trabajos del profesor Moxó, a cuyas obras remito como punto de partida en el estudio señorial, se hizo evidente la necesidad de emprender estudios específicos sobra la institución señorial y concretamente sobre señoríos en particular, ya que como hemos visto, buena parte de la población castellana vivió desde los siglos bajomedievales y aún avanzada la Edad Moderna bajo el régimen señorial. 
Desde comienzos de la década de los años setenta el proceso de señorialización de Castilla ha sido objeto de estudio de numerosos investigadores cuyos estudios han dado ya su fruto.

Algunos trabajos que en este campo se han realizado sobre un señorío específico, se ciñen a un momento histórico muy concreto y determinado en el tiempo; otros, por el contrario, bien por exceso o defecto en la documentación existente, se extienden sobre un período cronológico mucho mayor, en este último caso se analiza el régimen señorial como algo continuo, evolutivo y en transformación, hasta que tiene lugar la desamortización en el siglo XIX.

La mayor parte de los dominios señoriales estudiados corresponden atendiendo a su localización al área de Andalucía, siendo la Universidad de Sevilla una de las primeras Universidades que orientaron sus estudios hacia este campo; y al área meseteña, cuyos estudios partieron de la Universidad de Valladolid y de Salamanca.

Para concluir, quiero decir que a pesar del avance considerable que se ha producido en las investigaciones en torno al régimen señorial, queda aún mucho por hacer, y es de desear que este proceso iniciado siga y vaya en aumento, y a ello animo a nuestros alumnos pues cuanto mejor conozcamos esta institución, de la que hoy nos hemos ocupado, mejor conoceremos nuestra propia historia, ya que el R.S. es uno de los rasgos más característicos de la misma dentro del Occidente europeo. 


\section{BIBLIOGRAFÍA}

\section{A) CARÁCTER GENERAL}

Cadenas y Lopez, A., y Cadenas y Vicent, V., Elenco de grandezas $y$ tíiulos nobiliarios españoles. Madrid, Hidalguía, 1990.

CÁRDENAS, F. DE, Ensayo sobre la Historia de la propiedad territorial en España. Madrid 1873, 2 vols.

Contamine, P., La noblesse au Moyen Age. Essais à la mémoire de Robert Boutruche. (Coord.). Paris 1976.

DuBY, G., Seigneurs et paysans: Hommes et structures du Moyen Age (II). Paris, Flammarión, 1988.

Du Puy DE Clinchamps, P., La noblesse. Paris 1962.

GENICOT, L., La noblesse dans l'Occident médiévale. Paris 1982.

Moxó, S. DE, «Los señoríos: cuestiones metodológicas que plantea su estudio", en A.H.D.E., Madrid, XLIII, Madrid 1973, págs. 271-309.

- «Los señoríos. Estudio metodológico, en Actas de las Primeras Jornadas de Metodología Aplicadas de las Ciencias Históricas. Santiago de Compostela, 1975, págs. 163-173.

MuÑoz y Romero, Del Estado de las personas en los reinos de León y Castilla. Madrid 1988, (2. ${ }^{a}$ ed.).

Sempere y Guarinos, J., Historia de los vínculos y mayorazgos. Madrid 1847. 


\section{B) CARÁCTER ESPECÍFICO}

ACIEN, M., "Un ejemplo de repoblación señorial: la Serranía de Villaluenga», en Actas del Primer Congreso de Historia de Andalucia. Andalucía Medieval, II. Córdoba 1978, págs. 449-458.

Alfonso de Saldaña, I., "Las Sernas en León y Castilla. Contribución al estudio de las relaciones socio-económicas en el marco del señorío medieval», en Moneda y Crédito, núm. 128, 1974.

Álvarez Álvarez, C., El Condado de Luna en la Baja Edad Media. León 1982.

Álvarez, C., y Martín, J. A., "Señoríos nobiliarios en León a fines de la Edad Media», en León Medieval. Doce estudios. León 1978, págs. 199-218.

AndRÉs DíAz, R. DE, "Las fiestas de caballería en la Castilla de los Trastámaras», en La España Medieval. Estudios en memoria del profesor D. Claudio Sánchez Albornoz. Madrid 1986, t. I, págs. 81-107.

ATIENZA HERNÁNDEZ, I., "El poder real en el siglo XV: lectura crítica de los documentos de donación de villa y lugares. La formación de los Estados de Osuna». Revista Internacional de Sociología, núm. 48, 1983, págs. 557-591.

- Aristocracia, poder y riqueza en la España Moderna. La casa de Osuna, siglo XV-XIX. Madrid, Siglo XXI, 1987.

Barrios García, A., y Monsalvo, J. M., "Poder y privilegio feudales. Los señores y el señorío de Alba de Tormes en el siglo XV", en Revista Provincial de Estudios, núm. 7. Salamanca 1983, págs. 33-95.

BECEIRO PITA, I., «La conciencia de los antepasados y la gloria del linaje en la Castilla Bajomedieval», en Relaciones de poder, de producción y parentesco en la Edad Media y Moderna. Aproximación a su estudio. Madrid, CSIC, 1990.

- El Condado de Benavente en el siglo XV. Valladolid 1980. Tesis Doctoral.

- "La caza y la alta nobleza bajomedieval en el reino castellano", en Razo. Cahier du Centre d'Etudes mediévales de Nice, 1982, págs. 75-85.

- «La biblioteca del Conde de Benavente a mediados del siglo xv y su relación con las mentalidades y usos nobiliarios de la época», en $\mathrm{La}$ España Medieval, II. Estudios en memoria del profesor S. de Moxó, 1. Madrid 1982, págs. 135-145.

- «Los libros pertenecientes a los Condes de Benavente entre 1434 y 1530», en Hispania, XLIII. Madrid 1983, págs. 237-280. 
- «Luchas políticas y nobiliarias y resistencia antiseñorial en el reinado de Enrique IV: Ios conflictos de Castromocho y Carrión", en Actas del Primer Congreso de Historia de Castilla y León I, Edad Media. Burgos 1983, págs. 151-159.

- "Los Estados señoriales como estructura de poder en la Castilla del siglo XV", en Realidad e imágenes del poder en España a fines de la Edad Media. Valladolid 1988, págs. 293-324.

Benito Ruano, E., "Algunas rentas de Jorge Manrique», en Hispania, XXV, 1985, págs. 113-119.

Bermejo Cabrero, J. L., «Mayoría de justicia del rey y jurisdicciones señoriales en la Baja Edad Media castellana", en Actas de las Primeras Jornadas de Metodología Aplicada de las Ciencias Históricas. Santiago de Compostela 1975, págs. 207-215.

BoIs, G., «Noblesse et crise des revenus seigneriaux en France aux $x{ }^{\ominus}$ et $X V^{\ominus}$ siècle: essai d'interprétations", en La noblesse au Moyen Âge $X P^{\beta}-X V^{\beta}$ siècles. (Essais réunis por Ph. Contamines. Paris 1976, págs. 219-223.

BonaCHIA, J. A., El señorio de Burgos durante la Baja Edad Media (12551508). Universidad de Valladolid. Junta de Castilla y León. Salamanca 1988.

- «El concejo como señorío (Castilla, siglos XIII-xV)», en Concejos y ciudades en la Edad Media Hispánica II. Congreso de Estudios Medievales. Ávila, Fundación Sánchez Albornoz, 1990, págs. 429-464.

Cabeza SÁnchez-Albornoz, M. Cruz, La tierra llana de Ávila en los siglos XV y XVI: Análisis de la documentación del mayorazgo de la Serna (Ávila). Ávila, Institución Gran Duque de Alba, 1985.

Cabrera Muñoz, E., «La oposición de las ciudades al régimen señorial. El caso de Córdoba frente a los Sotomayor de Belazcázar", en Historia, Instituciones y Documentos, I. Sevilla 1974, págs. 13-39.

- «El señorío de Gahete e Hinojosa. Límites geográficos», en Actas de las Primeras Joinadas de Metodología Aplicada de las Ciencias Históricas. Santiago de Compostela 1975, págs. 247-255.

- "La fortuna de una familia noble castellana a través de un inventario de mediados del siglo XV", en Historia, Instituciones y Documentos, 2. Sevilla 1975, págs. 9-42.

- El condado de Belalcázar (1444-1518). Aportación al estudio del régimen señorial en la Baja Edad Media. Córdoba, Caja de Ahorros, 1977.

- «Tierras realengas y tierras de señorío en Córdoba a fines de la Edad Media", en Actas de Primer Congreso de Historia de Andalucía. Andalucía Medieval. Córdoba 1978, págs. 295-308. 
- «Usurpación de tierras y abusos señoriales en la sierra cordobesa durante los siglos XIV-XV》, en Actas de Primer Congreso de Historia de Andalucía. Andalucía Medieval II. Córdoba 1978, págs. 33-80.

- «El régimen señorial en Andalucía», en Actas del Primer Coloquio de Historia Medieval andaluza. Córdoba 1982, págs. 57-72.

- "Orígenes del señorío de Espejo y formación de su patrimonio territorial (1297-1319)", en La España Medieval, II. Estudios en memoria del profesor D. Salvador de Moxó, I. Madrid 1982, págs. 211-231.

- «Beatriz Pacheco y los orígenes del condado de Medellín», en Anuario de Estudios Medievales, 15. Barcelona 1985, págs. 513-555.

Cabrillana, N., "Salamanca en el siglo xv: nobles y campesinos", en Cuadernos de Historia, 3. Madrid 1969, págs. 255-295.

CALDERÓN ORTEGA, J. M. «Una aportación documental para el estudio de una hacienda señorial: los Álvarez de Toledo, señores de Valdecorneja», en Cuadernos Abulenses, 3. Ávila 1985, págs. 175-183.

- «La formación del señorío castellano y el mayorazgo de Rodrigo de Villandrando, conde de Ribadeo (1439-1448)", en Anuario de Estudios Medievales, 16. Barcelona 1986, págs. 421-447.

Canal Sánchez PaGin, J. M., "Otro caso de resistencia al régimen señorial: la merindad leonesa de Valdeburón en el siglo XV», en Hispania, XLIII. Madrid 1983, págs. 515-530.

CEPEDA, J., «La monarquía y la nobleza andaluza a comienzos del Estado Moderno», en Arbor, 21, 1952.

Clavero Salvador, B., «Behetría, 1255-1356. Crisis de una institución de señorío y de la formación de un derecho regional en Castilla», en Anuario de Historia del Derecho Español, 1974, n. 44.

- Mayorazgo. Propiedad feudal en Castilla (1369-1836). Madrid, siglo XXI, 1989.

- "Señorío y hacienda a finales del Antiguo Régimen en Castilla», en Moneda y Crédito, n. ${ }^{\circ} 135,1975$.

Collantes de TERÁN, A., «Los señoríos andaluces, análisis de su evolución territorial en la Edad Media», en Historia, Instituciones y Documentos, n. ${ }^{\circ}$ 6. Sevilla 1979, págs. 79-112.

Corral García, E., Las comunidades castellanas y la villa y tierra antigua de Cuellar (siglos XIII-XVI). Salamanca 1978.

Cremades Griñan, M. ${ }^{a} \mathrm{C}$., "Notas al sistema de encabezamiento de Alcabalas (1536-1556), en Homenaje a Torres Fontes, t. I. Murcia 1987, págs. 319-337.

DuART, C., "Vasallos y rentas de Diego Hurtado de Mendoza, III Duque del Infantado en la Merindad de Liébana en 1501 », en Altamira, XL. Santander 1976-77, págs. 231-246. 
Esteban Recio, A., Palencia a fines de la Edad Media. Una ciudad de señorío episcopal. Universidad de Valladolid, 1989.

ESTEPA DIAZ, C., «El realengo y el señorío jurisdiccional concejil en Castilla y León (siglos XII-XV), en Concejos y ciudades en la Edad Media. II Congreso de Estudios Medievales. Fundación Sánchez Albornoz, 1990, págs. 467-506.

Fernández Daza, C., El señorío de Burguillos en la Baja Edad Media Extremeña. Badajoz 1981.

Ferrari, A., Castilla dividida en dominios según el libro de las Behetrías. Madrid 1958.

Franco Silva, A., «El señorío de Villafranca de El Bierzo (siglos XIV y XV), en Boletín de la Real Academia de la Historia, CLXXIX, Cuad. I, págs. 91-105.

- «Bienes, rentas y vasallos del señorío de Villafranca del Bierzo al término del siglo XV", en Archivos Leoneses, núm. 69. León 1981, págs. 39-72.

- «El patrimonio señorial de los adelantados de Murcia en la Baja Edad Media», en Gades, núm. 7. Cádiz 1981, págs. 47-78.

- «La formación del señorío de los Vélez en Almería. Sus rentas y propiedades, 1492-1540", en Actas del Primer Coloquio de Historia Medieval Andaluza. Córdoba 1982, págs. 197-206.

- «El destino del patrimonio de Don Álvaro de Luna. Problemas y conflictos en la Castilla del siglo Xv», en Anuario de Estudios Medievales, núm. 12. Barcelona 1982, págs. 549-583.

- «El linaje Sandoval y el señorío de Lerma en el siglo XV», en Actas del Primer Congreso de Historia de Castilla y León, I. Edad Media. Burgos 1983, págs. 133-149.

- "Oropesa. El nacimiento de un señorío toledano a fines del siglo XV", en Anuario de Estudios Medievales, núm. 15. Barcelona 1985, págs. 299-315.

- «La hacienda de un noble castellano a comienzos del siglo XV», en La España Medieval. Estudios en memoria de Claudio Sánchez Albornoz, Madrid 1986, págs. 361-380.

- "Señores y campesinos en tierras de Soria a fines del siglo XV", en Homenaje al profesor J. Torres Fontes, t. I. Murcia 1987, págs. 524531.

FuRIO, A., «Tierra, familia y transmisión de la propiedad en el país valenciano durante la Baja Edad Media», en Relaciones de poder, de producción y parentesco en la Edad Media y Moderna. Aproximación a su estudio. Madrid, CSIC, 1990, págs. 305-328.

García Oro, J., Galicia en el siglo XVI. La nobleza gallega. Orense 1974. 
- «La nobleza gallega en el siglo XV», en Actas de las Primeras Jornadas de Metodología Aplicada de las Ciencias Históricas, II. Santiago de Compostela 1975, págs. 293-299.

- Galicia en la Baja Edad Media. Iglesia, señorío y nobleza. Santiago de Compostela 1977.

Gautier-Dalche, J., "Sepúlveda a la fin du Moyen Âge: évolution d'une ville castillane de la Meseta", en Le Moyen Âge, LXIX, 1963, págs. 805-828.

- «Le testament d'Alonso Martínez de Olivera: une fortune nobiliaire et une mentalité au début du XIV siècle, en Annales de la Faculté des Lettres et Sciences Humaines de Nice, núm. 30, 1978.

GENICOT, L., "Les hommes. La noblesse», en L'economie rurale Namuroise au bas Moyen Âge, vol. II. Louvain 1960.

- «La noblesse au Moyen Âge dans I'ancienne France», en Annales, Economie, Societé, Civilisations, 1962.

GeRBET, M. C., "Les guerres et l'accès a la noblesse en Espagne de 1465 a 1592", en Mélanges de la Casa de Velázquez, núm. 8, 1972, págs. 295-326.

- La noblesse dans le royaume de Castilla. Etude sur ses structures sociales en Estremadure de 1454 a 1516. Paris 1979.

- «Fermeture de la noblesse et parieté de sang dans les "concejos" de Castilla au XV siècle: à travers les procès d'Hidalguía", en La ciudad Hispánica, durante los siglos XIII al XVI, I. Madrid, Universidad Complutense, 1985-87, págs. 443-473.

- «Majorat, stratégie familiale et pouvoir royal en Castille d'après quelques exemples pris en Extremadure a la fin du Moyen Âge", en Les Espagnes Medievales. Mélanges offerts a Jean G. Dalché. Nice 1983, págs. 257-276.

- «Essai sur l'apparition d'une moyenne noblesse dans l'Estremadure de la fin du Moyen Âge", en Anuario de Estudios Medievales, núm. 16. Barcelona 1986, págs. 557-571.

- La nobleza en la Corona de Castilla. Cáceres, Diputación Provincial. I.C. El Brocense, 1989.

GIL OlcINA, A., La propiedad señorial en tierras valencianas. Valencia, del Cenia al Segura, 1979.

GÓmEz LORENTE, M., "Los señoríos en el reino de Granada: El señorío de Gor», en Cuadernos de estudios Medievales. Universidad de Granada, 1985-1987, págs. 61-74.

GóngorA, M., «Régimen señorial y rural en la Extremadura de la Orden de Santiago en el momento de la emigración a Indias", en Jahrbuch für geschichte von staat wirtschaft und gesseuschaft lateinamerikas, II. Colonia 1965. 
GonzÁlez CRespo, E., Elevación de un linaje nobiliario castellano en la Baja Edad Media: los Velasco. Madrid, Universidad Complutense, 1981, (Tesis Doctoral).

- "Los Arellano y el señorío de los Cameros en la Baja Edad Media», en La España Medieval, II. Estudios en memoria del profesor D. S. de Moxó, I. Madrid 1982, págs. 395-410.

- «Los Velasco en el horizonte dominical de la nobleza castellana según el Libro de las Behetrías", en Anuario de Estudios Medievales, núm. 14. Barcelona 1984, págs. 323-345.

- «El patrimonio de los Velasco a través de El Libro de las Behetrías. Contribución al estudio de la fiscalidad señorial», en Anuario de Estudios Medievales, núm. 16. Barcelona 1986, págs. 239-251.

GonzÁlez Gómez, A., «Moguer, un señorío medieval en tierras de Huelva», en Huelva en la Andalucía del siglo xv. Huelva 1976, págs. 99127.

GONZÁLEZ JIMÉNEZ, M., "Aportación al estudio de los señoríos andaluces. El caso de Carmona», en Homenaje al profesor Carriazo, III. Sevilla 1973, pág. 39-61.

González Mínguez, C., Fernando IV de Castilla (1295-1312). La guerra civil y el predominio de la nobleza. Valladolid 1976.

GonZÁlez RuIz-ZorRILlA, A., «La resistencia al dominio señorial: Sepúlveda bajo los Trastámaras», en Cuadernos de Historia, núm. 3. Madrid 1969.

Grassottl, H., «Hacia las concesiones de señorío con "mero y mixto imperio" en León y Castilla", en Homenaje a D. Claudio Sánchez Albornoz en sus noventa años, t. III. Buenos Aires 1985, págs. 113150.

- "Novedad y tradicción en las donaciones con "mero mixto imperio" en León y Castilla», en Homenaje al profesor Juan Torres Fontes, t. I. Murcia 1987, págs. 723-736.

GUILARTE, A. M., El régimen señorial en el siglo XVI. Valladolid, Universidad de Valladolid, 1987, (2. ${ }^{a}$ ed.).

HIGHFIELD, R., The Catholic kings and the titled nobility of Castille. Europe in the late middle ages. Londres 1975.

IGLESIAS, A., "Derecho municipal. Derecho señorial. Derecho regio", en Historia, Instituciones. Documentos, núm. 4. Sevilla 1977, págs. 115197.

INFANTE, J., Señorios jurisdiccionales del reino de Sevilla. Los Cespedes y su señorio de Carrión (1253-1874). Sevilla 1970.

LADERO QUeSADA, M. A., "Los señoríos medievales onunbenses", en Huelva en la Andalucia del siglo xv. Huelva 1976, págs. 65-97. 
- «Los señores de Gibraleón", en Cuadernos de Historia, núm. 7. Madrid 1977, págs. 33-95.

- «Rentas condales en Plasencia (1454-1488), en Homenaje al profesor Lacarra, IV. Zaragoza 1977, págs. 235-265.

- «Bibliotecas de la alta nobleza castellana en el siglo XV», en Livre et lecture en Espagne et en France sous l'Ancien Régime. Paris 1981, págs. 47-59.

- «Los señoríos medievales en el ámbito de Cádiz y Jerez de la Frontera", en La España Medieval, II. Estudios en memoria del profesor D. Salvador de Moxó. I. Madrid 1982, págs. 543-572.

- El siglo XV en Castilla. Fuentes de renta y política fiscal. Barcelona, Ariel, 1982.

- "Aristocratie et régime seigneurial dans l'Andalousie $d u x v^{e}$ siècle», en Annales E.S.C., nov.-diciembre, 1983, págs. 1346-1368.

- «Le seigneurie de Lepe et d'Ayamonte à la fin du $x v^{\circ}$ siècle: majorat, valeur et rentes», en Les Espagnes Médiévales. Mélanges o fferts à Jean Gautier Dalchè. Nice 1983, págs. 93-106.

- «De Per Afán a Catalina de Ribera. Siglo y medio en la Historia de un linaje sevillano (1371-1514), en La España Medieval, IV, Estudios dedicados a D. Ángel Ferrari. I. Madrid 1984, págs. 447-497.

- "La couronne et la noblesse au temps des Rois Catholiques (14651515). Ponencia del Coloquio sobre Pouvoir et Institutions dans Europe $d u x v f^{\circ}$ siècle. CESR. Tours, julio, 1984.

- «Economía y poder en la Castilla del siglo XV», en Realidad e imágenes del poder en España a fines de la Edad Media. Valladolid 1988, págs. 371-388.

LAMB, U., «La nobleza de sangre y los oficios tenidos por viles», en Hidalguía, 1955, págs. 295-298.

Lop Otín, M. ${ }^{a}$ J., "Un ejemplo del proceso señorializador extremeño: el señorío de Capilla (siglos XIII-X.VI), en La España Medieval, núm. 13. Madrid 1990, págs. 207-233.

LUIS LóPEZ, C. DE, La comunidad de villa y tierra de Piedrahita en el tránsito de la Edad Media a la Moderna. Ávila 1987.

MalPiCA, A., y, PeINAdo, R., "Relaciones entre los Condes de Urueña y la Catedral de Málaga (1462-1518), en Historia. Instituciones y Documentos, núm. 3. Sevilla 1976, págs. 417-439.

MARAVALL, J. A., "La sociedad estamental castellana y la obra de D. Juan Manuel», en Cuadernos Hispano Americanos, LXVII. Madrid 1966, págs. 751-768.

MARTín, J. L., "La sociedad media e inferior de los reinos hispánicos", en Anuario de Estudios Medievales, núm. 7. Barcelona 1970-1971, págs. 555-576. 
- "¿Campesinos de remensa en Castilla y León, (siglos XII-XIII)", en La España Medieval. Homenaje al profesor D. S. de Moxó. Madrid 1982, t. II, págs. 37-48.

Martínez Moro, J., La renta feudal en la Castilla del siglo xv: los Stuñiga. Valladolid 1977.

- La tierra en la comunidad de Segovia. Un proyecto señorial urbano (1088-1500). Valladolid 1985.

Martínez Sopena, P., El estado señorial de Medina de Rioseco bajo el Almirante Alfonso Enriquez (1389-1430). Valladolid 1977.

- La Tierra de Campos Occidental. Poblamiento, poder y comunidad del siglo $\times$ al XIII, Valladolid, Institución Cultural Simancas, Diputación Provincial de Valladolid, 1985.

MATA, R., «Participación de la alta nobleza andaluza en el mercado de la tierra: La Casa de Arcos (siglos XV-XVII), en Congreso de Historia rural, siglos XV-XIX. Madrid 1984, págs. 681-710.

Matilla TAscón, A., Declaratorias de los Reyes Católicos sobre reducción de juros y otras mercedes. Madrid 1952.

MAzo, F., "Los Suárez de Figueroa y el señorío de Feria", en Historia. Instituciones. Documentos, núm. 1. Sevilla 1974.

- El condado de Feria (1394-1505). Badajoz 1980.

- «El patrimonio de los señores de Feria en Andalucía", en Actas del Primer Congreso de Historia Medieval Andaluza. Córdoba 1982, págs. 207-217.

- «Propiedad y régimen de explotación en la Tierra de Barros a fines de la Edad Media", en La España Medieval, III. Estudios en memoria del profesor D. Salvador de Moxó. II. Madrid 1982, págs. 81-108.

MEYER, J., La noblesse bretonne. Paris 1966.

MITRE, E., «La emigración de nobles portugueses a Castilla a fines del siglo XIV», en Hispania, XXVI. Madrid 1966, págs. 513-526.

- «El asentamiento de nobles en el reino de León bajo los primeros Trastámaras", en Archivos Leoneses, núm. 42. León 1967, págs. 363-371.

- La evolución de la nobleza en Castilla bajo Enrique III (1396-1406). Valladolid 1968.

- «Señorío y frontera (El Marquesado de Villena entre 1368 y 1402)», en Murgetania, XXX, 1969, págs. 55-62.

- "Los cuadernos de cortes castellano-leonesas (1390-1407): Perspectivas para su estudio en el ámbito de las relaciones sociales», en Actas de las Primeras Jornadas de Metodologia Aplicada de las Ciencias Históricas. Santiago de Compostela 1975, págs. 281-291. 
MOLENAT, J. P., "Formation des seigneuries tolédanes aux $X \mathrm{XV}^{\mathrm{e}}$ et $X \mathrm{~V}^{\mathrm{e}}$ siècles", en Realidad e imágenes del poder en España a fines de la Edad Media. Valladolid 1988, págs. 349-370.

- «La volonté de durer: majorats et capellenies dans la pratique toledane des XIII-XV siècles», en La España Medieval, V. Homenaje a C. Sánchez Albornoz, t. Il. Madrid 1986, págs. 684 y ss.

MolinA GutiéRREZ, P., «Formación del patrimonio de los primeros Marqueses de Moya», en La España Medieval, núm. 12. Madrid 1989, págs. 285-304.

MONSALVo ANTÓN, J. M., "Poder político y aparatos de Estado en Castilla bajomedieval. Consideraciones sobre su problemática», en Studia Historica, Historia Medieval, IV. Salamanca 1986, págs. 100-167.

- El sistema Político Concejil. El ejemplo del señorio medieval de Alba de Tormes y su concejo de villa y tierra. Salamanca 1988.

- «Transformaciones sociales y relaciones de poder en los concejos de frontera, siglos XI-XIII. Aldeanos, vecinos y caballeros ante las instituciones municipales", en Relaciones de poder, de producción y parentesco en la Edad Media y Moderna. Aproximación a su estudio. Madrid, CSIC, 1990, págs. 107-170.

Morales Muñiz, D. C., "La política de mercedes del rey Alfonso de Castilla: el sostenimiento de su causa (1465-1468)", en Homenaje al profesor J. Torres Fontes, t. II. Murcia 1987, págs. 1125-1139.

MoReno Nieto, J. I., "Los Dávila, linaje de caballeros abulenses. Contribución al estudio de la nobleza castellana en la Baja Edad Media", en La España Medieval. En Homenaje al profesor D. S. de Moxó, t. II, 1982, págs. 157-172.

- "Mayorazgos arcaicos en Castilla», en La España Medieval, IV. Estudios dedicados al profesor D. Ángel Ferrari, II. Madrid 1984, págs. 695-708.

- «Algunas consideraciones y documentos sobre el régimen señorial en el tránsito de la Baja Edad Media', en Anuario de Estudios Medievales, núm. 16. Barcelona 1986, págs. 107-126.

Moreta Velayos, S., Malhechores feudales. Violencia, antagonismos y alianzas de clases en Castilla. Siglos XIII-XIV. Madrid 1978.

Moxó, S. DE, «Exenciones tributarias en Castilla a fines de la Edad Media", en Hispania, núm. 21. Madrid 1961, págs. 163-188.

- «Los señoríos. En torno a una problemática para el estudio del régimen señorial», en Hispania, núm. 24, págs. 1-54.

- «Disolución del régimen señorial en España», en A.H.D.E., XXXV, 1965, págs. 613-619.

- «El señorío, legado medieval», en Cuadernos de Historia, núm. 1, págs. 105-118. Madrid 1967. 
- «Los cuadernos de alcabalas, orígenes de la legislación tributaria castellana", en A.H.D.E., núm. 39. Madrid 1969, págs. 317-450.

- «De la nobleza vieja a la nobleza nueva. Transformación nobiliaria castellana en la Baja Edad Media", en Cuadernos de Historia, núm. 3. Madrid 1969, págs. 1-209.

- «La nobleza castellano-leonesa en la Edad Media. Problemática que suscita su estudio en el marco de una historia social", en Hispania, núm. 114. Madrid 1970, págs. 5-69.

- «La nobleza castellana en el siglo XIV, en Anuario de Estudios Medievales, VII. Barcelona 1970-71, págs. 493-513.

- "La venta de alcabalas en los reinados de Carlos I y Felipe II", en A.H.D.E., XLI, 1971, págs. 487-554.

- «El señorio de Vizcaya: Planteamientos para el estudio comparativo del régimen señorial hispánico en la Edad Media», en Edad Media y señoríos: el señorío de Vizcaya. Bilbao 1972.

- "Sociedad, Estado y Feudalismo», en Revista de la Universidad de Madrid, XX, núm. 78, 1972, págs. 177 y ss.

- «Los Albornoz. La elevación de un linaje y su expansión dominical en el siglo XII", en Studia Albornotiana, XII. Bolonia 1972, págs. 1980.

- «El patrimonio dominical de un consejero de Alfonso XI. Los señoríos de Fernán Sánchez de Valladolid", en Revista de la Universidad Complutense, XXII. Madrid 1973, págs. 123-162.

- Los antiguos señorios de Toledo, I.P.I.E.T. Toledo 1973.

- "Los señoríos: cuestiones metodológicas que plantea su estudio", en Anuario de Historia del Derecho Español, XLIII, 1973, págs. 271-309.

- "La sociedad en la Alcarria durante la época del Arcipreste", en B.R.A.H., t. CLXX, 1974, págs. 229-265.

- "La desmembración del dominio en el señorío medieval. Estudio sobre documentación de Aguilar de Campoo», en A.H.D.E., núm. 50, 1980, págs. 909-940.

- «El auge de la nobleza urbana y su proyección en el ámbito administrativo y rural a comienzos de la Baja Edad Media, 1270-1370", en B.R.A.H., núm. 178, 1981, págs. 407-505.

MuÑoz, M., El señorio de Castellanos. Badajoz 1964.

NiETO CUMPLIDO, M., «Luchas nobiliarias y movimientos populares en Córdoba a fines del siglo XIV", en Tres Estudios de Historia Medieval Andaluza. Córdoba 1977, págs. 13-65.

PADILLA, J., «Repoblación y creación del señorio de Espejo», en Actas del Primer Congreso de Historia de Andalucía. Andalucía Medieval, 1. Córdoba 1978, págs. 309-323. 
- El fundador y la fundación del señorío de Espejo (1260-1330). Córdoba 1981.

- «Pay Arias de Castro. Un ejemplo de la formación del patrimonio señorial de la nobleza cordobesa (siglos XIII-XIV), en Actas del Primer Coloquio de Historia Medieval Andaluza. Córdoba 1982, págs. 73-94.

PÁEZ, P., Síntesis histórico-politica del señorio y tierra de Molina. Guadalajara 1983.

PARDO, M. ${ }^{a}$ L., «Aportación al estudio de los documentos señoriales. El señorío de Medinaceli (1368-1454)", en Actas de las Primeras Jornadas de Castilla y León, I. Edad Media. Burgos 1983, págs. 127132.

PASTOR, J. L., «Un ejemplo de "Apanage" hispánico: el señorío de Villena (1250-1445)", en Revista del Instituto de Estudios Alicantinos, núm. 31. Alicante 1980.

PASTOR DE TOGNERI, R., "Historia de las familias en Castilla y León (siglos X-XIV) y su relación con la formación de los grandes dominios eclesiásticos", en Cuadernos de Historia de España, XLIII-XLIV. Buenos Aires 1967, págs. 88-118.

- (Comp.). Relaciones de poder, producción y parentesco en la Edad Media y Moderna. Aproximación a su estudio. Madrid, CSIC, 1990.

Peinado, R. G., «Fiscalidad señorial y tráfico comercial en Andalucía a finales de la Edad Media: notas para su estudio", en Actas del Segundo Coloquio de Historia Medieval Andaluza. Sevilla 1982, págs. 133-158.

Pérez Bustamante, $R$., «La resistencia de la villa de Santander al dominio señorial. Concesión y revocación de la villa por el rey Enrique IV al II Marqués de Santillana (1466-1472), en Altamira, XXXIX, 1975, págs. 1-60.

- «El proceso de consolidación de un dominio solariego en la Castilla bajomedieval. El señorío de la Vega, 1367-1432", en Altamira, XL, 1976, págs. 97-110.

- Señorío y vasallaje en las Asturias de Santillana (siglos XIII-XV). Santarder 1978.

Pérez-EMBID, J., "Don Álvaro de Luna, los monjes y los campesinos: un conflicto en la Castilla bajomedieval», en La España Medieval. Homenaje al profesor S. de Moxó. Madrid 1981, t. II, págs. 231-245.

PorRas, $P$., «El legado de la España Media: el régimen señorial en el reino de Jaén (siglos XV-XVIII)», en La España Medieval, IV. Estudios dedicados al profesor D. Ángel Ferrari, II. Madrid 1984, págs. 797831.

Porro, N., "Concesiones regias en la Institución de mayorazgo", en Revista de Archivos, Bibliotecas y Museos, LXX, 1962, págs. 79-99. 
- "La inalienabilidad de los bienes de mayorazgo. Tres documentos inéditos del siglo XV para su estudio", en Revista del Instituto de Historia del Derecho Ricardo Levene, núm. 21, 1970, págs. 125-166.

Pretel, A., Almansa medieval. (Una villa del señorío de Villena en los siglos XIII-XIV y XV). Albacete 1981.

QuesadA, T., «Huelma 1438-1511. Datos para la Historia de un señorío andaluz en el siglo XV", en Cuadernos de Estudios Medievales, VIVII. Granada 1978-79, págs. 237-267.

QuintANilla Raso, M. ${ }^{a}$ C., "Aportación al estudio de la nobleza en la Edad Media: La casa de Benavides", en Historia. Instituciones y Documentos, I. Sevilla 1974, págs. 165-219.

- "La casa señorial de Benavides en Andalucía», en Historia. Instituciones y Documentos, III. Sevilla 1974.

- "El señorío de la casa de Benavides", en Actas de las Primeras Jornadas de Metodología Aplicada de las Ciencias Históricas. Santiago de Compostela 1975, págs. 231-247.

- «El señorío de la casa de Aguilar: un dominio en la Campiña y un núcleo frente al Islam", en Andalucía Medieval. Nuevos estudios. Córdoba 1979, págs. 105-145.

- Nobleza y señoríos en el reino de Córdoba. La casa de Aguilar (siglos XIV-XV). Córdoba, publicaciones de la Caja de Ahorros, 1979.

- "La biblioteca del Marqués de Priego (1518)", en La España Medieval, I, estudios dedicados al profesor D. Julio González. Madrid 1981, págs. 347-382.

- "Haciendas señoriales nobiliarias a fines de la Edad Media», en Historia de la Hacienda española, épocas antigua y medieval. Madrid 1982.

- «Estructuras sociales y familiares y papel político de la nobleza cordobesa (siglos XIV-XV)», en La España Medieval, III. Estudios en memoria del profesor D. S. de Moxó, II. Madrid 1981, págs. 330-352.

- "Haciendas señoriales andaluzas a fines de la Edad Media", en Actas del Segundo Coloquio de Hacienda Medieval Andaluza. Sevilla 1982, págs. 53-65.

- «Nobleza y señoríos en Castilla durante la Baja Edad Media. Aportaciones de la historiografía reciente", en Anuario de Estudios Medievales, núm. 14. Barcelona 1984.

RIVERA GaRRETAS, M., "Organización municipal y gobierno de una ciudad señorial castellana en el siglo XIII: el caso de Uclés», en La Ciudad Hispánica durante los siglos XIII al XVI, II. Madrid, Universidad Complutense, 1985-87, págs. 929-956.

RodrigueZ, M. ${ }^{a}$ J., Señores y campesinos en Galicia: siglos XIV-XVI. Santiago de Compostela 1976. 
Rubio Pérez, L. M., El señorio leonés en los Bazán: Aproximación a su realidad socio-económica (1450-1460). La Bañeza (León) 1984, pág. 23.

Ruiz, J. M., «Consideraciones sobre la implantación de los señoríos en el recién conquistado reino de Granada», en Actas del Primer Congreso de Historia de Andalucia. Andalucía Medieval, II. Córdoba 1978, págs. 357-373.

SÁnCHEZ SAUS, R., «Los orígenes sociales de la aristocracia sevillana del siglo XV», en La España Medieval. Estudios en memoria de D. Claudio Sánchez Albornoz. Madrid 1986, págs. 1118-1139, t. Il.

Santos Canalejo, E. DE, «Piedrahíta, su Comunidad de Villa y Tierra y los duques de Alba en el siglo XV", en La España Medieval. Estudios en memoria de D. Claudio Sánchez Albornoz. Madrid 1986, t. II, págs. 1140-1174.

SANZ, M. J., «El señorío de Villalonso. Aproximación diplomático-histórica», en Actas del Primer Congreso de Historia de Castilla y León. Burgos 1983, págs. 221-232.

Segura, C., "Realengo y señorío en la tierra de Almería en el siglo XV», en La España Medieval, III. Estudios en memoria del profesor S. de Moxó, II. Madrid 1982, págs. 595-617.

SOlANo Ruiz, E., "La hacienda de las casas de Medina-Sidonia y Arcos en la Andalucía del siglo XV", en Archivo Hispalense. Sevilla 1972.

Stefano, L. DE, La sociedad estamental de la Baja Edad Media española a la luz de la literatura de la época. Universidad Central de Venezuela. Caracas 1966.

SuÁrez Fernández, L., «Nobleza y monarquía en la política de Enrique III», en Hispania, XII, Madrid 1952, págs. 323-400.

- Nobleza y monarquía. Puntos de vista sobre la historia política castellana del siglo $x \mathrm{~V}$. Valladolid 1975.

SzMOLKA, J., "Nobleza y autoritarismo en Andalucía. La contribución de Granada a la sumisión del estamento nobiliario andaluz, 1504-1510", en Cuadernos de Estudios Medievales, VI-VII, 1978-79, págs. 277296.

TAPiA, J. A., Vélez-Blanco. La villa señorial de los Fajardo. Madrid 1959. TORRES FonTES, J., La concesión del señorío de Molina a Juan Alfonso Fajardo. Molina de Segura 1975.

- «Los Fajardo en los siglos XIV y XV», en Miscelánea Medieval Murciana. Murcia 1978, págs. 107-177.

- «Mayorazgo y Testamento de Pedro Carrillo de Huete, halconero real y cronista de Juan II de Castilla», en Anuario de Estudios Medievales, núm. 17. Barcelona 1987, págs. 437-455. 
VAL VALDIVIESO, M. ${ }^{a}$ I., "Resistencia al dominio señorial durante los últimos años del reinado de Enrique IV», en Hispania, XXXIV, 1974, págs. 53-104.

- "Los bandos nobiliarios durante el reinado de Enrique IV», en Hispania, XXXV, 1975, págs. 249-293.

- "Reacción de la nobleza vizcaína ante la crisis bajomedieval», en La España Medieval, III. Estudios en memoria del profesor D. S. de Moxó, II. Madrid 1982, págs. 695-704.

VALDEÓN, J., "Notas sobre las mercedes de Enrique II de Castilla", en Hispania, XXVIII, 1968, págs. 38-55.

- "Movimientos antiseñoriales en Castilla en el siglo XIV», en Cuadernos de Historia, núm. 6. Madrid 1975, págs. 357-390.

- "Tensiones sociales en los siglos XIV y XV", en Actas de las Primeras Jornadas de Metodología Aplicadas de las Ciencias Históricas. Santiago de Compostela 1975, págs. 257-280.

- «Señores y campesinos en la Castilla Medieval», en Actas del Primer Congreso de Historia de Castilla y León, I. Edad Media. Burgos 1983, págs. 59-86.

VILLALba RUIz DE TOLEDO, F. J., “Reajuste de señoríos en el siglo XV: el trueque de Jadraque por Maqueda", en Homenaje a J. Torres Fontes, Murcia, t. II, 1987, págs. 1763-1779.

VILLALOBOS, M. ${ }^{a}$ L., "Los Stuñiga. La penetración en Castilla de un linaje de la nobleza nueva", en Cuadernos de Historia, núm. 6. Madrid 1975, págs. 327-355.

- "Régimen dominical en la provincia de Ciudad Real desde el siglo XII hasta fines del Antiguo Régimen", en VII Centenario del Infante $D$. Fernando de la Cerda (1275-1975). Madrid 1976, págs. 191-216.

- «Una fuente para el estudio del régimen señorial en España: el manuscrito de la Renta del Tabaco. Un ejemplo, Cádiz», en La España Medieval, III. Estudios en memoria del profesor S. de Moxó, II. Madrid 1982, págs. 717-730. 